\title{
BRITISH CATHOLICISM AND THE BRITISH ARMY IN THE FIRST WORLD WAR
}

\author{
by Michael SNaPE
}

$\mathrm{T}$ he history of British Catholic involvement in the First World War is a curiously neglected subject, particularly in view of the massive and ongoing popular and academic interest in the First World War, an interest which has led to the publication of several studies of the impact of the war on Britain's Protestant churches and has even seen a recent work on religion in contemporary France appear in an English translation. ${ }^{1}$ Moreover, and bearing in mind the partisan nature of much denominational history, the subject has been ignored by Catholic historians despite the fact that the war has often been regarded by nonCatholics as a 'good' war for British Catholicism, ${ }^{2}$ an outcome reflected in a widening diffusion of Catholic influences on British religious life and also in a significant number of conversions to the Catholic Church. However, if some standard histories of Catholicism in England are to be believed, the popular Catholic experience of these years amount to no more than an irrelevance next to the redrawing of diocesan boundaries and the codification of canon law. ${ }^{3}$ Certainly, the nature of Catholic historiography seems not to have comprehended the manifold significance of the Great War for the Catholic Church in Great Britain. The limited attention which British Catholicism and the First World War has received from historians has tended to be confined to studies of Catholic military chaplaincy and to studies of those Irish Nationalists who made the tragic choice of fighting for Britain on behalf of Ireland. ${ }^{4}$ Although perfectly valid in themselves, such studies hardly constitute a complete picture of the experience of Catholics in the British army during the First World War.

Although emigration and hardening Nationalist hostility to enlistment had served to reduce the proportion of Irishmen in the British army during the latter half of the nineteenth century, British Catholicism nevertheless harboured a strong military tradition at the outbreak of war in 1914. Although Catholics had secured commissions in the British army from as early as the American War of Independence, prior to Catholic Emancipation in 1829 their position was legally precarious, Catholics being ineligible to satisfy the terms of the Test Act if called upon so to do. ${ }^{5}$ However, in the post-emancipation era, the small Catholic presence among the officer corps was not only augmented by the influence of the Oxford Movement upon the élite sections of Victorian society from which the officer class was drawn but it also 
became much more assured. ${ }^{6}$ In 1890 , and following a distinguished military career, Sir James Charlemagne Dormer, a member of one of England's most prestigious Catholic families, became a lieutenantgeneral, dying three years later in India after being mauled by a tiger. ${ }^{7}$ During the Boer War, the considerable potential of the military profession for Catholic officers of ability was confirmed by the fact that two other Catholic officers, Sir William Butler and Thomas Kelly-Kenny, attained the rank of lieutenant-general during the course of the conflict. ${ }^{8}$ During the First World War, and largely because of the huge expansion of the army in the war years, at least nineteen pre-war Catholic officers served as general officers, among them being the Director of Military Intelligence from 1917 to 1918, Major-General George Macdonogh. ${ }^{9}$ In terms of the rank and file of the army, although the proportion of noncommissioned officers and other ranks recruited in Ireland fell by 18 percentage points between 1868 and 1898 (from nearly 30.8 per cent to 12.9 per cent), the proportion of Catholics in the army fell by only 11 percentage points over the same period (from 28.7 per cent to 17.7 per cent). Clearly, as Edward Spiers has inferred, these figures suggest that Irish Catholic immigrants in England and Scotland were much less susceptible to anti-enlistment influences than were their compatriots in Ireland itself. Indeed, by 1913, the army's own statistics seem to suggest that Catholic soldiers born outside Ireland were almost as numerous as Catholic soldiers who were Irish-born. ${ }^{10}$ Moreover, despite their continuing decline as a proportion of the army as a whole, in 1913 the proportion of Catholic non-commissioned officers and other ranks still comfortably exceeded the combined proportion of all non-Anglican Protestants (14.7 per cent of the army as compared to 13.7 per cent). ${ }^{11}$ By the end of the nineteenth century, the religious needs of Catholic soldiers were being met not only by their chaplains but also by a Catholic Soldiers' Association, a group which sought to ensure for serving soldiers regular access to Mass and to the sacraments. Besides this association of officers and chaplains, there was also the Confraternity for Catholic Soldiers, a confraternity which oversaw 'the spiritual interests of all Catholics in the army' through the distribution of devotional literature and by 'watching over the welfare of Catholics in military charitable institutions'. ${ }^{12}$

In addition to its significant presence in the army, British Catholicism had also proved susceptible to the spirit of Christian militarism which had swept mid and late-Victorian Britain and which had been manifested in the growth of the Volunteer movement in the 1850s and in the rise of the Boys' Brigades in the 1880s. Both the London Irish and the Liverpool Irish Volunteers were products of the Volunteer movement and were closely associated with the Catholic Church from their creation. ${ }^{13}$ Similarly, the Catholic Boys' Brigade, when founded by Fr. F. Segesser in Bermondsey in 1896, was simply the latest imitation of the original Boys' Brigade founded by William Alexander Smith in 
1883. The success of the Catholic Boys' Brigade was considerable, branches having been established throughout the British Isles by $1903 .{ }^{14}$ In the Diocese of Salford alone, the new organisation increased its membership from 250 to 3,000 between 1910 and $1913 .^{15}$ At the same time, and catering for a rather different clientèle the Catholic public schools were active in nurturing cadet organisations. Although the Oratory School did not form its own Officers' Training Corps until $1913,{ }^{16}$ it had become a vital part of the school's activities by the summer of $1914 .{ }^{17}$ At Stonyhurst, a Cadet Training Corps was formed in 1901, a body which was reorganised into an Officers' Training Corps several years later. By 1912, not only was the whole school in training on Monday and Thursday afternoons but Stonyhurst's O.T.C. was being pitted in training exercises against soldiers from the Preston garrison. ${ }^{18}$ Such developments appear to have been welcomed by the Catholic hierarchy, as the rapid spread of the C.B.B. would indicate. Few bishops, however, had such forthright views on this matter as Bishop Francis Bourne, who encouraged the formation of a cadet corps at St. Edmund's, Ware, and who wrote a pamphlet for the Duty and Discipline Movement on the necessity and desirability of universal military training which he entitled The Paramount Need of Training in Youth. ${ }^{19}$ Besides this enthusiasm for military drill and discipline, other factors were also indicative of British Catholicism's close ties with the military. Lady Elizabeth Butler, the pre-eminent military painter of the late Victorian era and the wife of General Sir William Butler, was herself a convert to Catholicism, ${ }^{20}$ while the popular figure of Kipling's Terence Mulvaney served as a strong literary reminder of Catholic Ireland's continuing links within the British army, irrespective of the stance of Irish Nationalists towards it. ${ }^{21}$ Among the Catholic hierarchy, army connections were also very much in evidence. According to the historians of Catholic military chaplaincy, ex-army chaplains were disproportionately represented among the canons and bishops of the English Catholic Church during the nineteenth century. ${ }^{22}$ At the outbreak of the First World War, the most conspicuous of these individuals was the Bishop of Nottingham, Robert Brindle D.S.O., who had accompanied both Wolseley's and Kitchener's expenditions to the Sudan and who had participated in the joint memorial service for General Gordon following the recapture of Khartoum in $1898 .{ }^{23}$ Finally, the Home Rule crisis in Ireland served to inject yet another strain of militarism into British Catholicism in the months leading up to the war. In November 1913, in response to the creation of the Ulster Volunteer Force earlier that year, the Irish Volunteers were formed in Dublin and subsequently extended their organisation to mainland Britain. ${ }^{24}$ Although, as an armed Nationalist organisation, the Irish Volunteers initially had an uneasy relationship with the Irish Catholic clergy, the clergy became conspicuous supporters of the movement as the Irish Parliamentary Party extended its control over it. ${ }^{25}$ Significantly, 
members of the Irish Volunteers, in response to the call of the Irish Parliamentary Party, were to provide a large proportion of Irish recruits for the British army during the First World War. ${ }^{26}$

The attitudes and behaviour of the Catholic Church in England and in Scotland during the First World War must be put into the context of an established tradition of demonstrating Catholic loyalty, and pressing Catholic claims, by capitalising upon Catholic participation in Britain's foreign wars. Linda Colley has shown how the loyalty and exploits of Irish Catholic soldiers during the Peninsular War emerged as a powerful argument for Catholic Emancipation after the Napoleonic Wars, ${ }^{27}$ but this same discourse also re-emerged during the Crimean War, when the Nationalist Freeman's Journal denounced moves to abolish the parliamentary grant for Maynooth College by invoking the heroism of Catholic Irish soldiers at Sebastopol. ${ }^{28}$ Nor did the Boer War pass without at least some of the Catholic clergy extolling the heroism of the Catholic Irish, notwithstanding the opposition of Irish Nationalists to Irish enlistment and even to the war itself. ${ }^{29}$ The war was fully endorsed by Francis Bourne, for example, who was then Bishop of Southwark and responsible for all Catholic chaplains in the British army. Similarly, on St. Patrick's Day 1901, Fr. Bernard Vaughan S.J., then rector of The Holy Name, Manchester, praised the Irish for the valour which they had recently displayed upon the battlefields of South Africa. ${ }^{30}$ If the military performance of the Catholic Irish made for good publicity for the Catholic Church in Britain during the Boer War, when war broke out in 1914 Catholics were conscious that it had come at the end of a long period of progressive emancipation and rehabilitation, a process which had been recently marked by the attendance of Edward VII at a Requiem Mass for the King of Portugal in 1908 and by the reformulation of the sovereign's accession declaration for the coronation of George V in $1910 .{ }^{31}$ Notwithstanding periodic eruptions of popular sectarian violence, given state funding for their schools, their growing involvement in national life and the trials and tribulations experienced by their co-religionists in France, Germany and Italy, from the standpoint of 1914 many Catholics in Britain saw good reason to look with gratitude upon the British state for the changes that had been effected to their condition over the preceding century. As an official account of Catholic participation in the war put it in 1916:

good citizenship is the first of Catholic social dogmas. One of the most striking features of recent English history has been the manner in which Catholics, inspired and fired by the freshness of their rejuvenated Faith and newly won liberties, stepped spontaneously into the forefront of their country's battles . . . It is no mean contribution of Catholics to the civil life of the Empire and no small testimony to their political vigour to have provided in this short space a Viceroy of India, a First Sea Lord, a Lord Chief Justice, a Colonial Premier, several Lord Mayors of London and other great cities, 
distinguished ambassadors and generals, and score upon score of men less eminent who have ... helped to keep going the machinery of the British Imperial administration and to make it what it is to-day.

Hence, when war broke out, it reasoned, 'it was not surprising that Catholics should have flocked to arms for the defence of the country they loved-and loved, not because it has admittedly treated them so generously and respected their devotion, but because it is their country and the instincts of patriotism are so deeply inrooted in all who bear the Catholic name., ${ }^{32}$ Nevertheless, despite the roseate picture of Catholic progress evoked by such sentiments, the fact remained that the wartime politics of Nationalist Ireland and the Neutral stance adopted by Pope Benedict $\mathrm{XV}$ did throw into question Catholic good faith during the course of the war. Naturally, this situation not only played into the hands of Orangeism and Unionism but it also served to erode national unity in Scotland and gave ammunition to other extremist Protestant organisations in England who were, as their aggressive response to the Eucharistic Congress of 1909 had shown, still determined to oppose greater Catholic integration into national life. ${ }^{33}$ In meeting the criticisms which Benedict XV and the position of Ireland engendered, Catholic apologists were compelled once again to resort to an established tradition of invoking the sacrifices of Catholic soldiers on the battlefield in order to refute charges of Catholic disloyalty.

In view of the circumstances of Germany's invasion of Belgium and of the undoubted atrocities which were attendant upon it, there seemed no doubt among Catholics in Britain that their country's part in the new European conflict fulfilled all the necessary criteria for a just war. Four days after Britain's declaration of war, on 8 August 1914, The Tablet applauded the government's actions, 'she goes into the fight', it said, 'with the knowledge that she is striking for the noblest of all causesfor the sake of human faithfulness, for the sanctity of treaties and of trust between nations. ${ }^{34}$ Bishop Casartelli of Salford, however, stated the case more carefully when he wrote, 'it must be our consolation that, as far as we can judge, our government has up to the last moment persistently and unwearyingly done its very best to prevent this great War and to keep clear of it; and that only the genuine conviction, at last forced upon our rulers, that both our national existence and our sworn pledges in a cause of justice have rendered the momentous step inevitable, and has finally decided them to unsheathe the sword. ${ }^{35}$ Although the justice of the war seemed perfectly clear, and was re-emphasised by Cardinal Bourne in the London Standard when the war was but a few weeks old, ${ }^{36}$ its outbreak provoked a response from the Catholic bishops of England and Scotland which was at once both prophetic and patriotic. Echoing the spirit of the prescribed prayers of the Mass in tempori belli, ${ }^{37}$ the bishops and clergy proclaimed that the war was a punishment from God upon a sinful generation. Cardinal Bourne's pastoral letter to the Archdiocese of Westminster, read on the first 
Sunday of the war, sadly proclaimed that 'war is in truth one of the greatest material evils that the world can see, but our Divine Master has warned us that it is an evil for which we must be prepared. ${ }^{38}$ Similarly, Bishop Casartelli wrote on 10 August 1914:

We must believe, according to the teachings of the Church, that war is indeed a grave evil, having its roots in the sins and passions of man. Secondly, both Holy Scripture and the Fathers and Liturgy of the Church teach us that, as with famine, pestilence and earthquake, Almighty God allows war as a scourge for the chastisement and healing of his sinful people. $^{39}$

Of course, the sin which had drawn down such an awful punishment on Europe was the apostasy of the modern age. Casartelli continued:

Can we deny that the Modern World, with all its boasted 'culture' and 'progress' has, especially during this and the last century, to a very great extent forgotten or denied its God, given itself up to a crude materialism, to gross sensuality, to the frightful abuse of marriage ... to the degradation of family life by divorce, to inordinate love of wealth and luxury, to greed and injustice,--in fact to a revived paganism? ${ }^{40}$

As the war dragged on, and its horrors became every more apparent, this conviction seems only to have grown stronger. In a sermon preached in St. Chad's Cathedral, Birmingham, in June 1915, Canon William Barry declared:

The greatest war that ever was might well seem to be the punishment of the greatest crime. Put the war into one scale, what sin shall we put into the other? I will tell you. In the most enlightened age since civilized life began man has forgotten God. The world has denied its Creator . . . The most enlightened was the most irreligious age ... Then the judgment came. Our day is a day of judgment. ${ }^{41}$

However, as a divinely-ordained punishment, some good could be expected to arise out of the war. In his Advent pastoral letter of 1914, Bishop Casartelli pointed to 'the wonderful revival of faith and religious practice in the French nation', a development which was complemented by an 'admirable outpouring of truly Christian charity' in Britain, particularly with respect to Belgian refugees. ${ }^{42}$ Similarly, preaching to men of the Cameron Highlanders at Invergordon in August 1914, Fr. Bernard Vaughan S.J. assured them that 'the sacrament of fire' through which they were about to pass 'would be for the cleansing of Europe, which would emerge chastened and purified by its purging flames. ${ }^{43}$ of course, there was additional consolation to be drawn from the consideration that, whatever the sins of Europe were in general, those of Germany were by far the most heinous. Despite Cardinal Bourne's support for the exchange visits of British and German churchmen which took place in the interests of Anglo-German amity in 1908 and 1909, and also the acknowledged example of Catholic organisation in Germany, ${ }^{44}$ few Catholics in Britain felt much affinity with the Prussian-led, post-unification German Empire. Germany was, of course, 
the cradle of the Reformation. More recently, it had been the breeding ground of biblical criticism and also the birthplace of divers atheistic philosophers such as Marx and Nietzsche. As recently as the 1870s, it had been the scene of outright persecution of the Church in the form of Bismarck's Kulturkampf. Hence, with Germany's invasion of Belgium and the declaration of war which followed it, Germany could be readily identified as the ultimate embodiment of that diabolical spirit of modernity which had so provoked the hand of the Almighty. Denounced by Casartelli as being consumed by 'an all-absorbing aggressive militarism' and as being in the grip of a 'latter-day paganism', Germany was widely depicted by the Catholic clergy and press in Great Britain as the neo-pagan, Protestant despoiler of Catholic Belgium, Poland and France. In October 1914, a Salford diocesan magazine declared:

The atrocities committed by the Germans in Belgium give rise to a suspicion that there must have been a motive of religious bigotry and of hatred of everything Catholic in the Prussian soldiers. It is a fact that only Protestant Martin Lutheran soldiers were sent to Belgium during the attacks on Liège, Namur, Louvain, and other places. ${ }^{45}$

In January 1915, The Tablet published a number of lurid accounts of German atrocities in France for the enlightenment of its own readership, accounts which emanated from the French government and which included the violating of a young nun in a commune in northern France and German soldiers dancing in a burning church in the Argonne. ${ }^{46}$ The destruction of churches at German hands remained a favourite subject for Catholic propagandists, a wartime pamphlet by Canon William Barry claiming that 'no fewer than one thousand six hundred' Catholic churches had been destroyed by German troops in Belgium, France and Poland. ${ }^{47}$ Needless to say, the entry of Turkey into the war on Germany's side provided yet more grist for this mill, Turkey's involvement in the war evoking in the minds of Catholic commentators memories of Lepanto and prompting demands for the banishment of Turkey from Europe and from the Holy Land. ${ }^{48}$ Indeed, as The Month observed in the light of the Armenian massacres, the Hun and the Turk were but two of a kind, 'The spirit of Pan-Germanism', it declared, 'is thoroughly Turkish in its arrogant self-preference and insolent contempt for other nations. ${ }^{49}$ In the heated atmosphere of the war, even the venerable Catholic Habsburgs could be depicted as some kind of malevolent, anti-Catholic force. Upon the death of the Emperor FranzJoseph in 1916, for example, The Month denounced Austrian rule over subject minorities as fundamentally unchristian and Austrian government in general as tending 'to Caesarism in the ecclesiastical and tyranny in the civil sphere'.

Before moving on to consider Catholics and the war effort in the rest of Great Britain, we must first note the complicating factor of Catholic Ireland during the war years. Catholic Ireland's attitude to the war was to become a source of acute recrimination in the rest of Great Britain 
and also a cause of great embarrassment for the leadership of the Irish Parliamentary Party, which had sought to overturn Nationalist hostility to Irish enlistment in view of the passage of Home Rule and the implications of the invasion of Belgium for the rights of small nations. ${ }^{51}$ Nevertheless, by the end of the war, only 6 per cent of Ireland's male population had joined the British army in comparison to over 20 per cent of the male population of England, Wales and Scotland. ${ }^{52}$ Moreover, although comprising only a quarter of Ireland's population, over forty per cent of the army's wartime volunteers from Ireland were Protestant, ${ }^{53}$ the Protestant contribution being conspicuous even in units raised outside Ulster. ${ }^{54}$ Consequently, despite the wartime fame of the Irish Guards and of the Royal Munster Fusiliers, many southern Irish infantry battalions were raised and sustained by virtue of thousands of recruits who enlisted outside Ireland ${ }^{55}$ and through the infusion of drafts of recruits and replacements from non-Irish regiments. ${ }^{56}$ Despite these measures, however, by the end of the war the original 10th (Irish) Division had lost its Irish title and was largely Indian in composition while the original 16th (Irish) Division contained only a single battalion from an Irish infantry regiment. ${ }^{57}$ As a result of these factors, the question of the scale of its contribution to the war effort has remained a vexed one ever since. David Fitzpatrick has argued that just over 200,000 Irishmen served in the armed forces during the First World War. However, other estimates have put the number of Irishmen who served in the British army during the First World War closer to half a million, a figure which would have to include those Irish who enlisted outside Ireland and all those who served in nominally Irish regiments. ${ }^{58}$ Certainly, the question of the scale of Catholic Ireland's wartime contribution is greatly complicated by the definition of Irish identity, for although Irish immigration into mainland Britain had been falling since the $1860 \mathrm{~s},{ }^{59}$ many Catholics of Irish birth and extraction living in England, Wales and Scotland retained a strong sense of their Irish identity and a marked sympathy for Irish national aspirations. These sentiments, moveover, generally co-existed and even competed with an interest in the political and social issues of their host societies and with other national loyalties. In 1915, the Archbishop of Glasgow appealed to just this sense of dual identity when he sought more volunteers from among the men of his diocese, men whom he simultaneously described as descendants of the Republican heroes of 1798 and of those men who had died around James IV at Flodden. ${ }^{60}$ Consequently, as early as the Boer War, a divergence between the attitudes of Catholic Ireland and of the Catholic Irish living in Britain had already become apparent. Early in 1900, a company of volunteers from the Liverpool Irish were given an ostentatious send-off before their departure for the seat of war, the 200 volunteers for the Royal Irish Regiment attending a special Mass at St. Patrick's church where they were addressed by Monsignor James Nugent, who had been their chaplain for some forty years. ${ }^{61}$ In 1914 , 
given the stance of the I.P.P.'s leadership and the various concessions granted to regional, occupational and even recreational identities in the raising of the 'Pals' divisions of the New Army, the Catholic Irish in mainland Britain were presented with a golden opportunity to demonstrate their dual loyalty to Ireland and to the British Empire. Although many of these volunteered directly for Irish regiments, the clearest demonstration of their enthusiasm was the formation of the Tyneside Irish Brigade, whose four battalions of Northumberland Fusiliers were formed at the initiative and with the support of prominent Nationalists on Tyneside. ${ }^{62}$

Although Nationalist sympathies clearly played a key rôle in bringing Catholics to the colours during the early months of the war, what is not so apparent is the part played by the Catholic Church in ensuring this response. Besides the pro-war posture which was rapidly adopted by the Catholic hierarchy, one of the factors which rendered British Catholic recruits susceptible to the demands of the hour was the educational policy which had long been pursued by the Catholic Church. In England at least, and often to the consternation of Irish Nationalists, the purpose of Catholic poor schools had been to provide their pupils not only with a sound Catholic education but also with a strong sense of English identity, a purpose which was served, among other things, by the promotion of the cult of the English Martyrs. ${ }^{63}$ Given the terms of the Catholic Church's own protracted struggle for acceptance in nineteenth-century English society, it was plainly self-defeating to nurture Irish or other national identities. ${ }^{64}$ As Gilley has put it, "there was virtually no attempt in the schools to conserve or create an Irish national culture, except in the sense of making much of St. Patrick's Day'. ${ }^{65}$ In this respect, Saint Patrick's school in Rochdale was probably typical of Catholic schools in that its portrait of Pope Pius X was hung alongside that of the king while the school was as sedulous in observing Trafalgar Day as it was in keeping the feast of Saints Peter and Paul. ${ }^{66}$ In a similar vein, at the height of the Boer War, the boys and girls of two Manchester missions were dressed in soldiers' and nurses' uniforms and ostentatiously paraded behind the Union flag. ${ }^{67}$ Moreover, besides this long-term policy of national integration, Catholic education also stood for conservative social values, stressing the need for deference, for social hierarchy and for contentment with one's lot. In its patriotic and social ethos, the character of Catholic education has been instructively compared to that of the Church of England ${ }^{68}$ and its effects certainly appear to have been reflected in the popular Catholic response to the outbreak of war in 1914.

Despite some early and isolated condemnation in the Catholic press of the nation's war fever and of 'the hysterical and hateful methods adopted to force the working men to join the colours, ${ }^{69}$ the Catholic bishops of England, Wales and Scotland soon threw their weight behind Lord Kitchener's recruitment campaign. Their attitude was exemplified 
by the Archbishop of Glasgow's words to the men of his diocese in a pastoral letter of July 1915 :

You need weigh no arguments, you need to consult no clergymen or professors-the case is too clear. You are asked to fight for Europe's religion and civilization against the powers of darkness sitting in high places; against the prince of this world; against ambition, treachery, cruelty, lust and robbery. ${ }^{70}$

As Cardinal Bourne had put the matter to 150 Lancashire recruits several months earlier, 'You could not have a nobler cause to defend ... In this war every reasonable man, who had tried to understand the real issues at stake . . can only give one answer. ${ }^{71}$ Although the Auxiliary Bishop of Salford's enthusiasm for the raising of a local Bantam battalion verged on the ridiculous, ${ }^{72}$ Bishop Hedley of Newport pronounced, with what was thought to be "his usual lucidity of expression and theological accuracy', that a good Catholic was

bound to help and support the civil state ... to which by God's ordinance ... he owes subsistence, order, peace and the means of serving God . . . the strengthening of the Army is a duty that presses on the community generally ... every man who is fit, and who is not lawfully hindered, will be doing what is meritorious and patriotic if he hastens to give his service in one capacity or another. The country is in grave danger, and anyone who neglects to help when he can help, violates the cardinal precept of Justice, and is, to a greater or lesser degree, guilty in the sight of God. ${ }^{73}$

Putting the same point rather more forcefully, Bishop Keating of Northampton declared that 'resistance to the external Aggressor is a religious as well as a patriotic duty . . . at such a crisis he who neglects the claims of patriotism is on a par with him who neglects the claims of his family. "He hath denied the faith, and is worse than an infidel.",74 The uncompromising pastorals of the English, Welsh and Scottish bishops, which were acclaimed in one Catholic publication as having 'emulated the crusade-preachings of St. Bernard' ${ }^{75}$ were repeated in Catholic magazines and newspapers and were often amplified by the endeavours of the lesser clergy, some of whom seem indeed to have adopted the methods and message of the crusading preachers. During the first weeks of the war, for example, Fr. Bernard Vaughan toured several Yorkshire towns calling for recruits in the name of truth, justice, freedom, and of God, England, and the Empire.' At Knaresborough, his words were endorsed by the local missioner, Prior John Ildefonsus Cummins O.S.B., who added that 'death in a worthy fight takes on much of the glory and some of the merit of martyrdom; it can atone for the folly and faults of an ill-spent life. ${ }^{, 76}$

Besides patriotism, peer pressure and a thirst for adventure, the stance adopted by the Catholic hierarchy at the outbreak of the war no doubt acted as an additional spur to Catholic recruits from mainland Britain. It was, in fact, a noted feature of the war years that the volunteer armies of the early war period contained a much higher proportion of churchgoers than did the largely conscript army of $1917-1918 .{ }^{77}$ Although the 
'Pals' divisions of the New Army contained a Glaswegian battalion raised from the Boys' Brigade (the 16th Highland Light Infantry) and a London battalion raised from the Church Lads' Brigade (the 16th King's Royal Rifle Corps), Catholics were no less affected by this contemporary mobilisation of the Christian faithful. In 1915, Bishop George Smith of Argyll and the Isles found that 'all the Catholic young men' of his diocese had 'long since gone to Flanders' ${ }^{78}$ but even south of the Highland line, in industrial areas without a comparable military tradition, the Catholic response was equally striking. It must, of course, be noted that the Tyneside Irish Brigade was not only a product of local Nationalist sentiment but also of what was recognised in a social survey of the $1920 \mathrm{~s}$ as the strongest religious denomination on Tyneside. ${ }^{79}$ Significantly, the raising of the brigade enjoyed the blessing of the Bishop of Middlesborough and the support of the Bishop of Hexham and Newcastle. ${ }^{80}$ Some idea of the scale of the nationwide mobilisation of the Catholic population can be gleaned from statistics compiled and published by individual dioceses, statistics which, even allowing for some exaggeration, serve as a telling indication of popular Catholic commitment to the war. In August 1915, it was reported that the Diocese of Southwark, whose Catholic population had been estimated at 150,000 in $1914,{ }^{81}$ had provided 'approximately 10,000 ' men for the forces. ${ }^{82}$ In the Diocese of Salford, whose Catholic population stood at around 295,000 in 1914, it was claimed by Bishop Casartelli in February 1915 that 18,000 men of his diocese had already enlisted out of a total male population of around 140,000 of all ages. ${ }^{83}$ By the time of the implementation of Lord Derby's attestation scheme in October, whereby all men between 18 and 41 were required to attest their willingness to join the colours when summoned, the diocese had furnished nearly 32,000 recruits for the forces. ${ }^{84}$ As in the nation at large, such recruits came from a broad range of social backgrounds. In the Diocese of Salford, Stonyhurst College could count more than 700 of its old boys under arms in $1916 ;{ }^{85}$ however, St. Joseph's Home, Patricroft, could take similar pride in knowing that 200 of its old boys had also enlisted by the end of $1915 .{ }^{86}$ Naturally, as with their counterparts in the Boys' Brigade and Church Lads' Brigade, the officers and the older members of the Catholic Boys' Brigade proved a ready source of recruits. In the Archdiocese of Westminster, in response to an appeal issued by Lord Esher, ${ }^{87}$ the leadership of the C.B.B. received permission to recruit a company for the second battalion of the London Irish Rifles from the ranks of the organisation. ${ }^{88}$ In time, these volunteers came to comprise the bulk of ' $\mathrm{H}$ ' Company, a company which, The Tablet noted with satisfaction in October 1914, was 'entirely Catholic' in composition. ${ }^{89}$ However, besides the C.B.B., the less militaristic male guilds and confraternities were no less affected by the call for men. In 1916, it was reported that 'Guilds and confraternities have given all their members of military age', the Little Oratory in London reportedly 
having not one man, married or single, remaining 'to be called up as a conscript, when the Military Service Acts were passed to bring in the lagging'. ${ }^{90}$ Although impossible to state precisely, the total number of Catholics who saw service in the British army during the First World War certainly ran into hundreds of thousands. Of around 42,000,000 people living in England, Scotland and Wales in 1914, an estimated $2,619,415$ (6.2 per cent) were at least nominally Catholic. ${ }^{91}$ During the course of the war, 4,836,700 men from these three countries either volunteered or were called-up for the army. ${ }^{92}$ Given that wartime conscription ultimately served to produce an army which very much reflected the character and composition of English, Welsh and Scottish society, a cautious estimate would suggest that at least 300,000 of these men were Catholics. ${ }^{93}$ To this figure must be added a minimum of 85,000 Catholic recruits and reservists from Ireland as well as around 33,000 men of the regular army of August $1914 .{ }^{94}$ Although crude and, if anything, conservative, these calculations would suggest that at least 400,000 British Catholics served in the British army during the course of the First World War.

The impressive response of the Catholic laity to the recruitment campaign of 1914-15 gave rise to a widely-aired assumption that Catholics were doing more than their fair share for the British war effort prior to the introduction of compulsory military service in 1916. By February 1915, Bishop Casartelli had already convinced himself that the proportion of volunteers provided by the Catholics of his diocese was 'very large, probably much larger than that of any other section of the community. ${ }^{95}$ Whether this was in fact the case is open to question, notwithstanding the impressive numbers of men yielded by the missions of his diocese and the high-profile recruiting activities of Alderman Daniel McCabe, the Liberal Lord Mayor of Manchester and the first Catholic to be elected to that office. ${ }^{96}$ A survey of the casualty lists of the 11th East Lancashire Regiment, the ill-fated 'Accrington Pals', which, despite its name, drew its recruits from a broad swathe of central Lancashire, suggests that Catholics were over-represented in the ranks of New Army battalions from industrial Lancashire, although not perhaps to the extent that Casartelli imagined. Of 252 Pals who died on the Somme in the first five days of July 1916, one in six were Catholics, a proportion only slightly greater than that of the Catholic population of Lancashire in 1914, which then stood at one person in seven. ${ }^{97}$ Nevertheless, in an early version of his Letter to a Catholic Soldier, Fr. Charles Plater also confidently asserted that, for the nation as a whole, 'the number of Catholics in the Army is larger in proportion than that of any other religious denomination. Catholic men have answered the call splendidly. ${ }^{98}$ How the Catholic proportion of Kitchener volunteers compared with that of other denominations is almost impossible to ascertain. Besides the wholesale destruction of individual service records during the Second World War, ${ }^{99}$ the question 
is further complicated by the position of Catholic Ireland, by the highly uneven distribution of Catholics among army units and by the fact that many recruits who gave a church affiliation upon enlistment would not have been communicants or recognised members of their stated denominations. Nevertheless, the scale of Catholic recruitment in mainland Britain was such that these recruits constituted a large element in many English and Scottish units and also provided a much-needed source of recruits for southern Irish regiments. Naturally, given their territorial associations, the presence of Catholics in most units of the British army tended to reflect the distribution of Catholics in the British Isles, a situation which was not significantly altered even after the introduction of conscription in 1916. As one Catholic chaplain put it in 1918, 'in many Lancashire battalions, in some Highland, and in most Irish, Catholics are in large numbers. But there are many English battalions which do not have more than twenty or thirty Catholics all told. And even this small number cannot keep together; they are broken up, and there will be eight in one company, five in another, three in another and so on. ${ }^{100}$ For Fr. Dominic Devas O.F.M., a posting to the 57 th (2nd West Lancashire) Division from the 48th (South Midland) Division in February 1917 meant significant changes to his work, 'Living now with Lancashire units,' he recalled, 'the proportion of Catholics was far higher than what I had been accustomed to, and one sad result of this was that $\mathrm{I}$ had far more funerals than before. ${ }^{101}$ Conversely, while seeking out Catholics behind the lines in France in January 1916, Fr. Francis Drinkwater was told there was not a single Catholic in an entire battalion of the Royal Inniskilling Fusiliers, a consequence of the fact that it had been entirely recruited from among the ranks of the U.V.F. Nevertheless, the situation was only marginally better among the battalions of the 46th (North Midland Division) to which he was subsequently attached, there being, by his own estimate, only half a dozen Catholics in a certain battalion of the Sherwood Foresters in February 1916. ${ }^{102}$

Catholic recruitment figures, however, were not the only means of demonstrating Catholic commitment to the war. The presence and posture of the staunchly patriotic Cardinal Francis Aidan Gasquet O.S.B. in the Vatican during the war years did much to assist Britain's diplomatic relations with the Holy See, which were re-opened shortly after the outbreak of hostilities. ${ }^{103}$ Meanwhile, England's other prince of the church, Cardinal Bourne, was equally active in demonstrating Catholic loyalty. Early in 1917, in an interview given to the Corriere d'Italia while on an extended visit to Rome, Bourne insisted that a 'Union Sacrée' was as evident in Britain as it was in France and assured the newspaper that 'one single idea animates all our men, from Commander-in-Chief to private: to carry the war through to victory, so that the world may enjoy a period of lasting and secure peace'. ${ }^{104}$ In March 1917, Bourne presided at a ceremony at Paray-le-Monial in 
Burgundy, the centre of devotion to the Sacred Heart. Since the reign of Louis XIV, this devotion had promised success to French armies which carried the symbol of the Sacred Heart on their standards. During the ceremony in March 1917, the flags of Britain and of other Allied nations were placed in the sanctuary's chapel while Bourne commended each nation in turn. ${ }^{105}$ Some weeks later, in June 1917, a special triduum was observed throughout Britain, France and Italy in which the Allied armies were formally consecrated to the Sacred Heart. ${ }^{106}$ In a similar vein, and this time at the instigation of The Universe, on the fourth anniversary of Britain's declaration of war, a Sunday which the nation observed as a day of prayer and intercession, more than 30,000 Catholic children in Great Britain made their communions for the intentions of Marshal Foch, who was not only the supreme commander of the Allied armies on the Western Front but was also noted for his exemplary life as a devout Catholic. Significantly, these children had already been praying for some months past for God to "bless our brave Generalissimo and crown his efforts with complete victory, to the greater glory of God and the good of a suffering world. ${ }^{107}$ In particular, the Catholic press made much of the heroism of Catholic soldiers irrespective of their nationality. A Catholic publication of 1916 spoke of the genius of the great Catholic generals who have led the undying chivalry of France and the unrivalled gallantry of the myriad soldierpriests and the "poilus", who, if not all, at least the great majority, are faithful to the Catholic traditions of their country [and] are one and all animated with the immortal spirit of St. Louis and the Maid of Orleans'. Similarly, the Catholic Irish were singled out as living embodiments of 'endurance, tenacity and pluck', while 'the strong Irish strain that runs through the contingents from the British Dominions' was viewed as contributing 'to the exploits of troops whom many experts consider to surpass all others in dash and bravery. ${ }^{108}$ Besides listing the recruitment and casualty figures of the great Catholic schools, ${ }^{109}$ the same publication listed eighteen Catholic winners of the Victoria Cross, including Lieutenant Maurice Dease, the first officer V.C. of the war, and Lance-corporal Edward Dwyer, the army's youngest V.C. to date. ${ }^{110}$ It was fortunate too, at least for the reputation of his Church, that the first British chaplain to be killed in the war was Fr. William Finn of the Diocese of Middlesbrough, who died while ministering to men of the 1st Dublin Fusiliers during the ill-fated landings at Sedd-el-Bahr, on the Gallipoli peninsula, in April 1915. The death of Fr. Finn and the treatment of Catholic V.C.'s were given extensive coverage by the Catholic press. Edward Dwyer's personal account of his meeting with George V, the award of his decoration and his reception by Cardinal Bourne at Westminster Cathedral later that day was reported verbatim in the pages of The Tablet. ${ }^{111}$ Likewise, when Sergeant Michael O'Leary of the Irish Guards was received by Cardinal Bourne in July 1915, The Tablet reported that he was told by the cardinal in sincere and simple 
language' that his valour 'not only redounded to his own credit, but added also to the glory of his regiment and of his race, and of the Faith the sergeant held. 112 Whatever else, the wider significance of his award was not lost on Edward Dwyer, who subsequently professed his wish 'to do some more to be more worthy of my country and my religion.'113 In contrast, the Catholic press adopted a deeply hostile stance towards conscientious objectors and to those it deemed to be 'slackers'. Of the latter, The Month fumed shortly after the introduction of conscription in January 1916, that 'they have done what lay in them to spoil the nation's record of devotedness to duty. Our consolation is that they are so comparatively few.' 114 As for the former, their position was denounced as supremely arrogant if not positively heretical. According to Catholics of the British Empire and the War, in the Catholic moral system 'the profession of arms' had 'ever been an honourable one, and the Christian soldier has been and still is the beau ideal of a chivalry which no modern theories have been able to destroy.' In contrast, the conscientious objector, guided only by 'the freaks and vagaries of individual opinions' had 'no place in the Catholic Church'. ${ }^{115}$ The fact that the Catholic Church did not condemn killing in a just war, rendered a Catholic conscientious objector who protested the inherent sinfulness of war a heretic in all but name. Nevertheless, the war did produce a handful of Catholic conscientious objectors who were prepared to dispute the justice of the war, leaving their prison chaplains to wrestle with the problem of whether to admit such men to the sacraments. ${ }^{116}$ Moreover, if conscientious objectors could expect little sympathy at the hands of the Catholic press, then so too could captured zeppelin and Uboat crews, the execution of whom was endorsed in principle by The Month in January 1917 on the grounds that such men 'destroyed noncombatants by unlawful methods in undefended ships and towns.' 117

Despite all these manifestations of patriotic ardour, there remained the intractable problems of Catholic Ireland and Benedict XV, both of which, like the comparatively minor problem of German religious in Britain, played into the hands of British critics of the Catholic Church. Although several members of the Irish hierarchy expressed their support for recruiting as late as $1916,{ }^{118}$ such support was by no means typical of the Irish clergy as a whole. Pro-Austrian and anti-French sentiments were detectable among a minority of the Irish clergy who favoured the Catholic Habsburgs above the secular Third Republic, ${ }^{119}$ but the prevailing mood among the Catholic clergy in Ireland appears to have been one of apathy. Not only were the Irish clergy notably lukewarm on the subject of recruiting, they were also reluctant to come forward as army chaplains, a factor which was instrumental in creating a widely perceived shortage of Catholic chaplains in the army as a whole. ${ }^{120}$ However, with the passage of the third Military Service Act in April 1918, clerical apathy towards voluntary recruitment was stirred into outright hostility towards the threat of conscription for Ireland, which 
had been spared this measure by the Act's predecessors of 1916. The Irish hierarchy instructed Masses to be said with the purpose of averting conscription and clergymen were prominent at anti-conscription meetings. ${ }^{121}$ As a Maynooth professor put it in an article for the Irish Ecclesiastical Record in June 1918, conscription imposed by 'the Imperial Parliament' was invasive not only of the life and liberty of individuals but of the rights of the Irish people themselves, 'an inhuman and oppressive measure which Irishmen may lawfully resist by the most effective means at their disposal'. ${ }^{122}$ With the loyalty of Ireland further thrown into question by the Easter Rising and by growing Republican sentiment, the posture of the Irish clergy towards the war naturally undermined demonstrations of Catholic loyalty in England and Scotland. If Ireland was not sufficient embarrassment, there was also the problem of Benedict XV. Despite the Pope's work on behalf of prisoners of war and early calls in church quarters for Vatican mediation in the conflict, ${ }^{123}$ the pontiff's neutrality and determined efforts on behalf of a negotiated peace won him few supporters in Britain. If Benedict's position provoked hostility among British Protestants, it met with a paltry response from British Catholics, being productive only of a small and beleaguered Guild of the Pope's Peace which earned the public condemnation of Bishop Burton of Clifton and which was pointedly ignored by contemporary editions of The Catholic Directory. ${ }^{124}$ More worryingly, Benedict's efforts were often construed in the worst possible light by much of the British press, so much so that Cardinal Bourne saw fit to caution the Pope on his peace-making strategies in February 1917. ${ }^{125}$ However well-intentioned, Benedict XV's Peace Note of August 1917, coming after three years of bitter conflict, did more to antagonise than to conciliate public opinion in Britain. Following the Italian rout at Caporetto two months later, the Morning Post detected the hand of the Vatican in the Italian collapse, a charge vigorously refuted by Cardinal Bourne. ${ }^{126}$ Several months later, in his popular magazine John Bull, Horatio Bottomley launched a stinging attack on the Vatican, claiming that papal dreams of recovering the papal states lay at the bottom of the Pope's allegedly pro-German sympathies and activities. Significantly, it was not only populist newsmen such as Bottomley who found fault with the Pope's position. In his poem Mansoul of 1918, Rudyard Kipling condemned the Pope in apocalyptic terms which deliberately echoed the anti-papal rhetoric of Bunyan's Pilgrim's Progress. In Scotland, too, old sectarian tensions were on the increase by 1917, the Pope being by this time firmly bracketed with the Central Powers by the Presbyterian church press. ${ }^{127}$ One very prominent Scottish Presbyterian, Sir Douglas Haig, occasionally confided the frustration and suspicion he felt towards the Catholic Church and its representatives in the pages of his personal diary. In August 1918, for example, Haig noted with disapproval the absence of Catholic chaplains from a joint religious service held at G.H.Q. ${ }^{128}$ More significantly, in 
October 1917, at the height of the Passchendaele offensive, Haig had expressed his exasperation with discouraging intelligence reports with the words, 'I cannot think why the War Office Intelligence Dept. gives such a wrong picture of the situation except that Gen. Macdonagh ... is a Roman Catholic and is (unconsciously) influenced by information which doubtless reaches him from tainted (i.e. Catholic) sources.' ${ }^{129}$ Following the eruption of the German spring offensive on 21 March 1918, Haig voiced his suspicions as to the reliability of Catholic Irish troops with a harsh assessment of the behaviour of the 16th Division, writing in his diary entry for 22 March, 'Our 16th (Irish) Division ... is said not to be so full of fight as the others. In fact, certain Irish units did very badly and gave way immediately the enemy showed. ${ }^{, 130}$

The Catholic hierarchy and media countered suspicions and accusations with publicity of their own. Charges concerning the Pope's conduct were answered by invoking the catholicity of the Church and by alluding to the papacy's historic peacemaking role. ${ }^{131}$ In June 1918, The Universe rose to John Bull's challenge by publishing a rebuttal entitled "John Bull" and the Pope: Some Plain Words on a Plain Issue, a response which was even published in pamphlet form. This response emphasised the Pope's position as the head of a global church and his duty to be both neutral and impartial. Furthermore, it argued that the Pope had condemned the invasion of Belgium and that he had spoken out against atrocities for which Germany was primarily responsible. It also played upon the ironic fact that the German press was fully convinced that the Pope was pro-Allied. As for the restoration of the papacy's temporal power by Germany and Austria-Hungary, The Universe insisted that the pope was not so naive as to blunder down this particular path. Rounding on Bottomley's attendant condemnation of the Irish hierarchy and its stance on conscription, The Universe pointed to similar opposition among the overwhelmingly Protestant white population of South Africa. ${ }^{132}$ Despite the comprehensiveness of this answer, there were signs that the cumulative weight of adverse publicity was beginning to tell by 1918 . In March The Month denounced the so-called 'Pope-Baiters' of the British press, accusing them of attempting to foment sectarian discord 'throughout the British Commonwealth' and of weakening 'the moral influence' of 'the only supra-national authority in the world. ${ }^{133}$ Five months later, it inveighed against what it now termed 'the Anti-Catholic press', accusing it of attempting to foment discord among Catholics in Canada and in the British Isles. ${ }^{134}$ However, and notwithstanding repeated explanations of the nature and role of the papacy, the best defence against any anti-Catholic slurs in the emotionally-charged atmosphere of the war appears to have been the sacrifices made by Catholic soldiers. As early as September 1915, these were passionately invoked in a remarkable outburst by the Bishop of Clifton after the Anglican bishop of Birmingham, Dr. Henry Russell 
Wakefield, had made an unguarded remark concerning the status of Catholics as 'guests of the nation':

The Anglican Bishop of Birmingham has allowed himself to indulge in an expression that will be widely resented. Forgetting that his so-called National Church, which has never been the Church of the entire nation, was conceived in Germany, though brought forth in England, was nursed by German and Germanizing divines, and forced upon freeborn Englishmen with the aid of German mercenaries, he informs us, who, out of all proportion to our numbers, are engaged in a crusade against the ultimate product of German Lutheranism on the fields of France and Belgium, that we, as Catholics, are 'the guests of the nation'. A murrain on his hospitality! ${ }^{135}$

Likewise, in March 1918 The Month fulminated against Britain's 'popebaiters' by bitterly reflecting that 'it is to protect these men thus employed that Catholic soldiers are dying in France and Flanders! And people are found to cry shame on Catholic Ireland for showing no eagerness to make the like sacrifice!'136

Besides the sacrifice of their lives, the Catholic Church in England and Scotland also valued the religious example of its soldiers. The circumstances of army life threw a heavy onus on Catholic soldiers to maintain the observance of their faith independent of the supportive influences of home. As Charles Plater admonished, 'a man in the army may have very little to help him to practise his religion. There are no women relatives to get him out to Mass and the Sacraments. There are no Catholic clubs or societies to keep him in a Catholic atmosphere. He may have to go for a long time without seeing a priest or being able to get to Mass. In short, he has to depend on himself. There is a great temptation to slack. ${ }^{137}$ Despite the disruptions attendant on active service, the frequent unavailability of chaplains and the uncooperative attitude of some officers and N.C.O.s, Catholic chaplains were often impressed by the efforts made by their soldiers to get to mass and the sacraments. According to Fr. Henry Day S.J., "there were always Catholic soldiers who managed to know instinctively the time and place of Mass, and the whereabouts of their chaplain. Such men were rarely deprived for long of the comforts and help of religion. ${ }^{138}$ Likewise, in France in 1915, Fr. Francis Drinkwater noted in his diary the case of a Private J. Higgins of the King's Own Yorkshire Light Infantry, whose successful attempt to get to Mass without first obtaining a pass earned him punishment for his insubordination. ${ }^{139}$ Although, in France, Flanders and Italy at least, the absence of a chaplain could be compensated for by the presence of a nearby Catholic church, when faced with a prolonged lack of contact with either, there is evidence to show that Catholic soldiers fell back on the most popular collective devotion which could be performed in the absence of a priest, namely the recitation of the rosary. One Birmingham Oratorian recalled how he was reprimanded by an Irish private for intruding on a soldiers' rosary in Salonika in $1918,{ }^{140}$ while another chaplain, Fr. Donal O'Sullivan, once 
encountered a small group of Catholic soldiers in France who had been without contact with a chaplain for some months. These men told him that 'when they left England they agreed never to miss their morning and night prayers and when ever possible to meet every night and say a decade of the rosary together and this they had done [for] 11 months except the nights when they were actually fighting and could not move from their own places'. ${ }^{141}$ The public rosary was also observed among soldiers in captivity, the diary of Sergeant Charles Mills of the Royal Munster Fusiliers testifying how he and his fellow Catholics met together for their May devotions every evening in their German prison camp in May 1918. ${ }^{142}$ The devout behaviour of Catholic soldiers also elicited favourable comments from non-Catholic observers. The Anglican chaplain Julian Bickersteth was struck by Catholic soldiers who served at a Mass he attended at a parish church in France in 1916, writing 'it was curious to see these two in their service uniforms and muddy boots kneeling on either side of the priest during the mass. At least they were not ashamed of witnessing to their faith. ${ }^{143}$ Similarly, J. G. Bennett, a Wesleyan minister attached to the Y.M.C.A. in Mesopotamia, noted with warm approbation the conduct of Catholic soldiers at a Palm Sunday Mass in Baghdad in $1917 .{ }^{144}$ Moreover, as in matters of faith, so too in matters of morals, it being one of the proud boasts of Fr. McShane of the 16th Division that it had the lowest incidence of V.D. of all the British divisions on the Western Front. ${ }^{145}$

One of the other aspects of the religious example of Catholic soldiers was the deference which they were perceived to show towards their chaplains. Even the Irish-born socialist writer Patrick Macgill, who was far from uncritical in his view of the Church, professed pride and admiration for his chaplain, Fr. Richard Lane-Fox, of the London Irish Rifles. ${ }^{146}$ Moreover, Robert Graves noted how, during heavy fighting on the Somme, men of a Scottish battalion were led back to their positions by a Fr. McCabe. 'They were Glasgow Catholics', he explained, 'and would follow a priest where they wouldn't follow an officer. ${ }^{, 147}$ Such attitudes were not confined to citizen soldiers, however, and were also to be found among the remnants of the pre-war regular army. Following their ill-fated landing at Sedd-el-Bahr, an Anglican naval chaplain noted the genuine grief with which Fr. William Finn was mourned by the men of the 1st Dublin Fusiliers, regular soldiers whom he thought 'well-nigh worshipped' their deceased chaplain. ${ }^{148}$ Such natural deference could, however, have more questionable corollaries, the Jesuit chaplain Fr. William Doyle noting how, during bombardments, men of the 16th Division would seek his company as though his presence alone would be sufficient to keep German shells at bay. ${ }^{149}$

In view of their example, Catholic soldiers were frequently depicted as exemplars of the faith to the Catholic faithful at home. Such depictions reflected an established Catholic taste for the holiness of simplicity and demonstrated a marked sympathy for an unsophisticated, 
working-class piety which was not often evinced by Protestant observers of the religious state of the British army. ${ }^{150}$ Unlike these more demanding observers, Catholic chaplains and commentators found much to commend in the simple religious attitudes and uncritical demeanour of their co-religionists in khaki, letters and articles concerning the edifying behaviour of the Catholic Tommy becoming a staple feature of Catholic papers and magazines during the war years. This image of soldierly Catholic piety achieved national status through Fortunino Matania's celebrated wartime painting The Last Absolution of the Munsters at Rue Du Bois 1915 and was one which Catholics were evidently keen to impress upon Protestants. For example, when a Protestant officer commented to Fr. Henry Day on the evident fondness for medals and rosaries evinced by Irish soldiers at Gallipoli, Day airily replied, 'Yes, they are soldiers of Christ and Our Lady, as well as soldiers of the King. ${ }^{151}$ Seemingly unaware of Catholic devotional aesthetics, military historians of the Catholic Irish contribution to the war have uncritically accepted and rehearsed this view of the Catholic soldier ever since. ${ }^{152}$ Certainly, this abiding and exalted view of the piety of the Catholic Tommy took hold very quickly. In December 1914, for example, The Tablet published an euphoric letter from a chaplain of the 4th Division:

The faith of the old Crusaders was not in it, and wherever you went and while you remained with these faithful Catholic men, nothing else was anything to them. God bless them all, for they have given me more joy in these three months than the whole rest of my semi-wasted life has given me. It was worth waiting for. It is true to say that the German Kaiser is fighting a community of saints ... 153

Such glowing appraisals led to the assertion that Catholic soldiers did indeed die as crusaders, even as martyrs. In a sermon preached in June 1915 at a Requiem Mass for the fallen of Birmingham's Catholic missions, Canon William Barry asserted:

To die for a righteous cause, not seeking one's own, is to imitate the Martyrs by witnessing, as they did, that man's nature is founded on the idea and the law of absolute morality, to which all else must be sacrificed . . . Sons of Crusaders, descended from men and women who suffered unto death for conscience sake, well they understood how to be loyal to their country and their God ... ${ }^{15}$

Likewise, in a sermon preached in Bayswater on 4 November 1917, just after his return from his second tour of the Western Front, Cardinal Bourne invoked the example of the soldiers whom he had recently visited in urging that spirit of resigned and patient suffering among the faithful which he felt would help to bring about the end of the war. ${ }^{155}$ Of all British Catholics to die in khaki, it was Major William Redmond, the Nationalist M.P. for East Clare and the brother of John Redmond, who attracted the most individual attention. Described by a colleague as the most devout of the Irish Parliamentary Party's M.P.s, ${ }^{156}$ Redmond 
was killed on Messines Ridge in June 1917 while serving with the staff of the 16th Division. In his will, made in December 1916, Redmond wrote that should he die on active service he would die 'a true Irish Catholic, humbly hoping for mercy from God, through the intercession of His Blessed Mother, whose help I have ever invoked all through my life.' The pious sentiments of Redmond's will, along with other details of his patriotism and his devotion to the Virgin Mary, were widely reported in the Catholic press following his death and Requiem Masses were said for him in many Catholic churches. ${ }^{157}$ When Cardinal Bourne made his second and much-publicised visit to the Western Front in the autumn of 1917, he made a particular point of visiting Redmond's grave at Locre, where the cardinal and dozens of assembled chaplains recited the De Profundis. ${ }^{158}$

A telling indication of the symbiotic link between the Church in the ranks and the Church at home lay in the efforts made by Catholic civilians on behalf of the spiritual and material welfare of their soldiers. As early as October 1914, Fr. Peter Grobel launched a nationwide appeal for Catholic newspapers and devotional aids for wounded soldiers. ${ }^{159}$ The Tablet consequently contrived to put together sixpenny packets of essential items which were deemed to serve their 'Catholic needs'. The items which comprised this 'devotional outfit' were listed as:

'1 Simple Prayer Book (C[atholic] T[ruth] S[ociety])

1 Pamphlet (selected, C.T.S.)

1 Rosary

1 Scapular Medal

1 Sacred Heart Badge. ${ }^{160}$

Not only were prayers and Masses constantly offered for those on active service and for those who had fallen, but new prayer books and devotional manuals were also composed for the men, manuals such as Fr. Casgrain's The Catholic Soldiers' and Sailors' Prayer-Book of 1917 and a companion volume entitled For the Front: Prayers and Considerations for Catholic Soldiers, which was published anonymously the following year. The tone of these manuals was predictable enough: Catholic soldiers were admonished to be pious, loyal, obedient and efficient. They were urged to pray, to attend the sacraments and to avoid bad company. Moreover, and drawing upon a distinctively Catholic view of suffering, the Catholic Tommy was urged to offer up his sufferings in atonement for his sins, this being 'the most excellent reparation we can offer for our own sins and those of other men, and the most powerful prayer that we can make for ourselves and others. ${ }^{161}$ In addition to all of this, the Jesuit Charles Plater wrote his Letters for Catholic soldiers, led retreats for them and initiated a private correspondence scheme which was run from a Dominican convent in Leicester. ${ }^{162}$ Nor, indeed, were the Catholic wounded or Catholic prisoners of war forgotten. During the war years, the Duchess of Norfolk opened a home for the 'totally incapacitated and incurable' at Littlehampton in Sussex, 
preference being given to unmarried Catholic men, ${ }^{163}$ while the British Knights of the Sovereign Military Order of St. John of Jerusalem forwarded parcels of food and clothing to British Catholic prisoners of war in Germany and Austria. ${ }^{164}$ With the vast expansion of the armed services during the early months of the war, a major effort was expended in providing clubs and huts for Catholic soldiers. The earliest facility of this kind appears to have been St. Patrick's Catholic Soldiers' Club, which was opened by Fr. Grobel in a room in Boulogne in October 1914. ${ }^{165}$ By the end of the war a number of these huts and clubs had been established in various locations from Ripon to Lourdes and were under the overall management of a Catholic Hut Council. Often staffed by members of the Catholic Women's League, which had its own Huts Committee, these institutions provided chapels as well as catering and recreational facilities. ${ }^{166}$ As a wartime publication of the C.W.L. put it, although open to all comers, 'the first object of a Catholic Soldiers' Recreation Hut is to bring Catholic Soldiers into touch with one another in a Catholic atmosphere, and to give them facilities to practise their religion. ${ }^{167}$

In view of the confidence so widely invested in the religious calibre of Cathoic soldiers, they were soon being co-opted as missionaries for the faith. Charles Plater's Letter to a Catholic Soldier of 1916 warned his readers that 'men are beginning to turn to the Catholic Church, and it largely depends upon you what they will think about it. You are in the limelight now. People are watching you. They are watching you to see whether you live up to the Faith which you profess. If you do not, they will have none of it. They hate a sham, and they judge the Catholic Church not so much from books as from what they see in you. ${ }^{168}$ Similarly, the anonymous author of For the Front maintained after two further years of war that 'perhaps the best way the Catholic religion can be preached nowadays is by the example of Catholic laymen who have to live in the world with all sorts of men and yet manage to carry out their religion faithfully. ${ }^{169}$ The potential for the missionary work into which Catholic soldiers were thus co-opted was vast indeed. In an article for The Tablet in February 1915, an anonymous chaplain signing himself 'MISSIONARIUS' confidently proclaimed, 'soldiers it was who first brought the faith from Rome to England, long before the landing of St. Augustine. Soldiers, it may be, are destined, on their return from the present war, to re-introduce the faith into this much de-Christianized nation. ${ }^{170}$ Although 'MISSIONARIUS' believed it was the example of his fellow chaplains and the fortifying effects of the sacraments upon Catholic soldiers which would help to win over their Protestant comrades, ${ }^{171}$ some less exalted tactics could be employed in the wartime bid to win converts for the Church. One night at a camp in England in January 1916, for example, after Charles Plater had rendered some practical assistance to a drunken soldier who was one of his flock, the soldier concerned 
'proceeded to wake up a Church of England neighbour and said: "You ought to be an R.C. I bet your parson wouldn't put you to bed if you got drunk". 172

Catholic soldiers were cast not only as missionaries among the army but as exemplars of the faith among the civilian populations of France and Belgium. As a Jesuit army chaplain wrote in 1915, 'I do not like the behaviour of the French in their churches; that of the Belgians is better, but that of our British Catholic soldiers is best of all, and I am proud to say that their outward reverence in presence of the Blessed Sacrament, always an indication of and a stimulus to recollection, has constantly been remarked upon by these people, who did not believe until we rubbed it in, that a Britisher could really be a Catholic.' ${ }^{173}$ Likewise, in March 1916, William Doyle, who was then acting as the de facto cure of Mazingarbe in the coalfields of northern France, wrote of his men: "it is an object lesson to the parlez-vous to see the crowds who come to Mass and Communion daily and Benediction in the evening. ${ }^{, 174}$

The relative strength of army Catholicism during the First World War was partly reflected in a significant crop of wartime converts, a harvest which was also apparent in the French army at this time. ${ }^{175}$ In 1912, just over 6,500 people became Catholics in England and Wales. By 1917 , the number of conversions had risen to $9,000 .{ }^{176}$ In July 1917, Willie Doyle, who was himself an active proselytiser, felt that a reported figure of 13,000 soldier converts since the war began was 'much below the mark' ${ }^{177}$ Fully aware of the multi-factorial and longterm nature of many conversions, Fr. George Stebbing wrote in 1930 that 'either directly or indirectly through the War a very large number of individuals have been received into the Catholic Church, who otherwise, humanly speaking, would have remained outside. Well-informed observers have estimated this number for England at 70,000; but clearly it is not a matter on which a numerical estimate is likely to be of a very great value. ${ }^{178}$ Significantly, perhaps the most famous British soldier of the Great War to convert to Catholicism, Siegfried Sassoon, was not to be received into the church until 1957. Nevertheless, during the war years Catholicism was undoubtedly a missionary force, and was certainly viewed as such by non-Catholics. Significantly, one of Kitchener's professed reasons for not doing more to encourage recruitment in Catholic Ireland during the early months of war was because he felt that the Catholic Irish 'would only bring their priests with them and start wholesale proselytising. ${ }^{179}$ Certainly, the memoirs and diaries of Catholic chaplains contain numerous references to soldiers under instruction ${ }^{180}$ and the Catholic press did devote considerable coverage to some notable cases of soldier converts. ${ }^{181}$

According to Maisie Ward, who served as a volunteer nurse in England during the war, 'the numbers of men who joined the Church in the trenches witnessed to a craving for the supernatural, the need of a 
truth to live by, a religion to die in. ${ }^{182}$ The reasons for the appeal of Catholicism for non-Catholics were related, though not identical, to the reasons which seem to have ensured the survival of the Faith among Catholics themselves. Firstly, in a highly sacerdotal religion such as Catholicism, there was the all-important question of the Catholic chaplain. Despite a lack of chaplains with the original B.E.F. of 1914, Catholic army chaplains were to become much thicker on the ground as the war progressed, a favourable establishment of chaplains being authorised by a War Office which had long grown sensitive to the religious needs of Catholic soldiers. ${ }^{183}$ According to establishments which came into force in January 1917, English and Scottish divisions were allowed four Catholic chaplains and nine Anglican or Scottish Presbyterian chaplains. In the case of the army's two southern Irish divisions, nine chaplains were required to be Catholic. ${ }^{184}$ In June 1917, Julian Bickersteth, who was at that time an Anglican chaplain with the 56th (1st London) Division, bemoaned the paucity of Anglican chaplains in comparison with the ubiquity of their Catholic counterparts: 'It makes me despair of the Church of England', he wrote, 'Rome makes no mistakes. We have no fewer than five Roman priests in our division for barely 400 R.C.'s, and at the present moment only six C of E chaplains. Frantic appeals for more make no difference. ${ }^{185}$ At the end of the war, by which time the effect of casualties, conscription and the falling off of recruitment in Ireland probably meant that the percentage of Catholics in the army approximated to the percentage of Catholics in the population of mainland Britain, there were 651 Catholic chaplains in the British army, ministering to about six per cent of its soldiers, as opposed to 1,985 Anglican chaplains ministering to over seventy per cent. ${ }^{186}$ In the light of their numbers and relative ubiquity, it may well be that the popular reputation of Catholic chaplains during the war years represented a consolidation and development of the Church's pre-war reputation for the pastoral care of its urban poor, a reputation which had been a distinguishing feature of British Catholicism in the nineteenth century and which had even earned Catholic priests a grudging measure of respect from many working-class Protestants. ${ }^{187}$ Besides their pastoral zeal, Catholic chaplains were often thought to be endowed with a great degree of spiritual authority than were their Protestant counterparts. Although assumed by Catholics and freely claimed by the likes of 'MISSIONARIUS', this authority was also conceded by many Anglican chaplains who felt that their own sacramental rôle was often eclipsed by their performance of other duties, particularly those relating to the function of entertainments officer. ${ }^{188}$ Moreover, as was apprehended by Anglicans and Catholics alike, the confused doctrinal position of the Church of England scarcely helped the standing of the Anglican chaplain. ${ }^{189}$ In June 1917, Oswin Creighton, an Anglican chaplain with the 3rd Division, wrote gloomily but revealingly: 
I often wonder if it would not be better if all the men were RCs. For men who don't think, and have no initiative, what can you have but a dogmatic, authoritative, externally imposed religion? And even the men who do think are often quite prepared to submit to authority and accept unquestioningly the dogmas for the sake of the unity and strength that are gained. I am always absorbed in insoluble problems, the RCs have none. Everything of immediate importance is settled. I believe that is what makes most RC padres so unfailingly cheerful, often boisterous. ${ }^{190}$

The tacit recognition of the spiritual authority of the Catholic chaplain could take many forms among non-Catholic soldiers. Robert Graves, who reckoned Anglican chaplains to be 'remarkably out of touch with their troops', remembered how, just before the battle of Loos, the Anglican chaplain of the 2nd Royal Welch Fusiliers had preached an impassioned sermon on the battle against sin, prompting one old soldier to remark, 'Christ, as if one bloody push wasn't enough to worry about at a time.' In contrast, the Catholic chaplain had simply 'given his men his blessing and told them that if they died fighting for the good cause they would go straight to Heaven, or at any rate would be excused a great many years in Purgatory.' ${ }^{191}$ Notwithstanding his Irish Protestant background, Field Marshal Harold Alexander recalled much later in life "what a strength and comfort it was to me when, as a young subaltern in the Irish Guards during the First World War, I knelt with my men on the battlefield before the attack and received that spiritual support given to us all, both Protestant and Catholic, by our Regimental Chaplain'. ${ }^{192}$ Finally, Catholic chaplains may have been the beneficiaries of some adverse publicity concerning their Anglican colleagues who, in the early months of the war, had been instructed to remain with their brigade field ambulances rather than venture into the front line, an instruction which earned them an unjust and lasting reputation for malingering as a result. ${ }^{193}$ In fact, there were some sharp differences of opinion among the Catholic clergy as to the proper place for a military chaplain. Although Cardinal Logue and William Doyle saw the chaplain's place as in the firing lines of the fighting regiments, ${ }^{194}$ Francis Drinkwater took a more circumspect view, writing in March 1918 that the presence of Catholic chaplains with the field ambulances, which by then appears to have been the prevailing practice, was in fact 'the ideal arrangement' ${ }^{195}$ That this should have been so had been explained as early as November 1914, when an anonymous Catholic chaplain had written:

My own experience satisfies me that a chaplain is better attached to a field ambulance, as when he becomes regimental, the three other regiments of his brigade see little of him . . . regimentally one can see only the wounded of one's own particular unit, whereas in the ambulance all the brigade pass under the observation of the chaplain. As for giving the last Sacraments on the field of battle, that under the existing conditions of war is impossible. Men are either killed at once or their wounds are attended to in the ambulance in a very short time. ${ }^{196}$ 
In addition to the rôle and reputation of Catholic chaplains, the conditions of the war appear to have had a subtle catholicising effect on British culture. The huge scale of mortality promoted the saying of prayers for the dead in the Church of England and even led some Scottish Presbyterians to re-evaluate the theology of purgatory. ${ }^{197}$ On the Western Front, where Britons came into contact with a Catholic landscape in numbers unprecedented since the Reformation, innumerable remarks were made as to the survival of wayside calvaries and of crucifixes in ruined churches. Most famously, a wartime legend concerning the end and outcome of the war arose around the so-called 'Golden Virgin' of Albert, a statue of the Virgin and Child which leaned precariously from the tower of the town's shattered basilica. ${ }^{198}$ This was a landscape which also influenced the commemorative architecture of the war, as the form of numerous public and private war memorials erected both during and after the war readily testifies. ${ }^{199}$ The diffusive influence of Catholic culture was also evident in what countless British soldiers chose to wear for their personal protection. Although the wearing of personal mascots was already established in pre-war Britain, ${ }^{200}$ the circumstances of war and their popular association with good luck made the wearing of personal mascots almost endemic among British soldiers during the war years. Obviously, many mascots were seen and used as nothing more than secular lucky charms, but a significant cultural aspect of the war does appear to have been the widespread appropriation of Catholic devotional objects for this purpose. In February 1915, 'MISSIONARIUS' wrote, 'thousands of Protestant soldiers are wearing the medal of Our Lady, invoking her name with faltering but half-believing lips, and begging their Catholic friends at home to send them more cigarettes, more soap and more medals.' 201 According to William Doyle, by 1917 the possession of rosary beads or Catholic religious medals was so widespread among British soldiers as to be meaningless as an indication of denominational allegiance. ${ }^{202}$

Certainly, the Church took an extremely dim view of the belief that mascots of any kind, even religious ones, were capable of bestowing protection in and of themselves. As The Month pointed out as early as 1915 , to a properly instructed Catholic soldier a devotional object such as a medal or a scapular was simply a 'badge of trust' in the omnipotent power of God and in the intercessory power of the Virgin. ${ }^{203}$ The proper use of such objects was told by a Catholic Tommy who had been caught in a barrage on the Western Front, 'I was thinking at the time that it was like hell. But I felt, somehow, that Our Lady would see us through, so I just gripped my rifle with my one hand, and said my beads with the other. ${ }^{204}$ Nevertheless, despite all this, it would seem that even some Catholics were not quite clear on the proper use of such devotional objects. Although having had the benefit of a secondary education at a Jesuit college, Edwin Campion Vaughan was clearly taking no chances when he moved up into the front line in August 
1917 , 'I . . . saw that my rosary was sewn into my tunic', he wrote in his diary, "with the sovereign that Marie had given me for luck, and that my holy medals were firmly attached with my identity discs to my braces. ${ }^{205}$ Similarly, as Mary Heimann has observed of civilian devotion to the rosary in Victorian England, 'the line between piety and superstition was not always drawn sharply,206 and the conspicuous attachment of Catholic soldiers to their rosary beads does raise the suspicion that they were viewed as more than devotional aids in the strictly orthodox sense. One Irish officer, writing for the Daily Chronicle in 1917, observed that "in the change and chance and turmoil of active service, many things get lost, but the Rosary beads seem to be always treasured, and every soldier at Mass seems to have them. Prayer-books are often missing, but the Rosary, as a rule, never is., ${ }^{207}$ Moreover, there are grounds to believe that, as on the home front, the war may have served to generate an unhealthy interest in chain prayers among Catholic soldiers, an interest which was censured by the Church and which stemmed from the protection against sudden death and injury which such prayers were thought to bestow on their devotees. ${ }^{208}$

Besides his piety, the level and content of his religious education was thought to be one of the distinguishing features of the Catholic soldier. In sharp contrast, a monumental ignorance in this respect was thought to characterise the bulk of Britain's citizen army, pundits of the mainstream Protestant denominations ascribing this situation to a wholesale failure in their methods of religious instruction. ${ }^{209}$ Catholic soldiers, however, were considered to be the important exception to this general rule. One letter to the Church Times from an Anglican padre at a base hospital, which was readily seized upon by The Tablet, reported:

We have a splendid R.C. here now, and he simply goes into a ward and calls out, “Any R.C.'s here?" Up pops a head. "Yes, Father." His people are taught to expect him, and know what he will do when he comes. I go to a man marked C/E. I talk to him. He knows nothing; he expects he has been baptized, and beyond a hazy idea that there is a mysterious Somebody called God somewhere, Who is very angry with him, but can be coaxed . . . he knows nothing., 210

Again, in The Month later in 1915, another Anglican chaplain was quoted as saying:

The almost entire ignorance of the average soldier of the elements of religion ... is simply appalling. A Roman Catholic soldier knows at once what to do-he asks for a rosary to help him say his prayers; he asks you to get him a priest; he wants his Communion or to make his confession. He knows the Gospel of Christ; he understands about repentance, about grace, about the presence of the unseen army of saints and angels. Our poor Tommy, not from any fault of his own, but from our neglect, is quite unconscious of most of this as a reality. ${ }^{211}$

Naturally enough, Catholic observers came to see in such discrepancies a clear vindication of the value and quality of Catholic education, rele- 
vant examples from the press persuading Archbishop Thomas Whiteside of Liverpool to allege that religious education had generally failed outside the Catholic Church. ${ }^{212}$ One of the reassuring characteristics of this Catholic religious education was, of course, its clear and unambiguous content. As Gerald Parsons has observed, 'unlike the other majordenominations in Victorian Britain, Roman Catholicism did not enter the twentieth century with a de facto theological pluralism within its bounds. On the contrary, it retained a position of doctrinal orthodoxy and theological unity which set it sharply apart from the other major denominations. ${ }^{213}$ Nor was this doctrinal conservatism deemed to be a point of weakness; in fact, it is quite likely that the Church's robust stand against its own radicals was completely vindicated as a result of the war, Maisie Ward recalling that her mother eventually came to rejoice 'that Modernism had suffered defeat in the Catholic Church before the war, for it would have been terrible if any of our priests had thought of Confession as a mere form, of the Host he laid on these men's lips as a mere symbol, ${ }^{214}$ Obviously, the horrors of the war did not pose quite the same challenge to orthodox Catholicism as they did to the confident and progressive assumptions of many liberal Protestants who seemed, so Francis Drinkwater noted in August 1918, in spite of all evidence to the contrary, to believe in the unlimited perfectibility of mankind en masse.,215

Culturally, too, many practising Catholics were probably better prepared for the hardships of military life than were many practising Protestants, not least because Catholicism in England and Scotland at the beginning of the twentieth century was still to a large extent 'a religion of the slums'. ${ }^{216}$ Unlike some of the major Protestant denominations of England and Scotland, which often drew most of their members and communicants from the upper and middle classes, the principal social constituency of the Catholic Church in mainland Britain was undoubtedly the urban working-class. In 1914, the Catholic strongholds of mainland Britain lay in Clydeside, in Merseyside, in the north-east of England, in the rougher parts of London and in the cotton towns and coal-fields of Lancashire. One of the corollaries of this situation was that, whereas members of the unskilled working class were rarely to be seen in many Protestant congregations, they were a strong component of the Catholic congregations of industrial Britain. ${ }^{217}$ The urban working-class background of most British soldiers has been seen as providing a key explanation for the robust performance of the British army during the First World War. As John Bourne has shown, by 1916 the British army was 'an overwhelmingly working-class, urban army' and its impressive cohesion during the war reflected many of the characteristics of contemporary British working-class life, notably its conformity, its subordination and its stoicism in the face of adversity. ${ }^{218}$ Despite numbering an Oxford don among their ranks (one Arthur Brandreth, a pre-war convert, who, according to an obituary, was 
'blown to pieces for justice sake' on All Saints Day, 1916) ${ }^{219}$, the civilian background of most Catholic soldiers from mainland Britain was distinctly proletarian. Coming from a civilian background of what has been described as 'normal deprivation', 220 the Catholic working-class soldier, like his Protestant counterpart, came to the army at least partly inured to the boredom, discomforts and horrors which it had to offer, simply exchanging, as Bourne has suggested, 'one set of hardships for another.' ${ }^{221}$ In the light of this, the social background of most Catholic soldiers no doubt rendered them less likely to revolt against the trials of military life and the terrible business of war. Besides the social background of the majority of its soldiers, the Catholic Church also possessed a moral code which was probably more adaptable to the mores of army life than were the traditional moral strictures of many Protestant churches. For example, while condemning foul and blasphemous language and stressing the importance of sexual purity, the Catholic Church took a relatively relaxed view of such classic Protestant taboos as drinking and gambling, vices which were as prevalent in the army as they were in contemporary working-class life. ${ }^{22}$

Besides these advantages in coming to terms with the nature and customs of military life, many Catholic soldiers could also take some advantage of the surroundings in which they found themselves when abroad. Although the ravaged Catholic landscape of France and Belgium made a strong impression on the minds of many Protestant soldiers, this landscape was certainly more familiar and probably more consoling to their Catholic counterparts. For example, French and Flemish churches were often frequented by Catholic soldiers and appropriated by their chaplains for worship. ${ }^{223}$ In 1915 , prior to the battle of Loos, the Catholics of one infantry brigade even took charge of a makeshift church inherited from the French army, subsequently repairing its tabernacle and installing an oil lamp, pictures and even an altar cover. $^{224}$ Other forms of native religious activity were also more accessible to Catholic soldiers. In September 1917, for example, Fr. Francis Drinkwater noted how he had attended 'a big procession of the Blessed Sacrament at Bethune' and how he had been accompanied on this occasion not only by French civilians but also by a sizeable contingent of British soldiers. ${ }^{25}$ By 1918, British Catholics on the Western Front were taking advantage of their location by participating in organised pilgrimages to Lourdes, courtesy of sundry benefactors in Britain. By the end of the war, Lourdes was home to a British army chaplain and also to a Catholic Soldiers' Club. ${ }^{226}$ In a more distant theatre of war, namely Palestine, similar circumstances could also obtain. On the Feast of the Assumption in 1918, British Catholics of the Egyptian Expeditionary Force participated in an Army Catholic Congress held in Jerusalem, the highlight of the event being a mass pilgrimage to the holy sites of the city. ${ }^{227}$ Reflecting on his recent visits to Bethlehem and Jerusalem, one Catholic soldier of the E.E.F. who was not unappre- 
ciative of the good fortune which he had enjoyed in visiting foreign climes, wrote a wry letter home to his mother: 'I used to think I would like to have a trip down the Mediterranean but never dreamed that it would be my fortune to have one "buckshee" (that's the Arabic equivalent of free, gratis, all for nothing!) . . . Much less did I think I would also have the fortune to tour the Holy Land-also "buckshee",228

In the light of the preceding discussion, we can appreciate the factors which led Philip Gibbs, one of Britain's leading wartime journalists, to write in his Realities of War:

Catholic soldiers had a simpler, stronger, faith than men of Protestant denominations, whose faith depended more on ethical arguments and intellectual reasonings. Catholic chaplains had an easier task. Leaving aside all argument they heard the confessions of the soldiers, gave them absolution for their sins, said Mass for them in wayside barns, administered the Sacraments, held the cross to their lips when they fell mortally wounded, anointed them when the surgeon's knife was at work ... The old faith ... was still full of consolation to those who accepted it as little children, and by their own agony hoped for favour from the Man of Sorrows who was hanged upon a cross, and found a Mother-love in the vision of Mary, which came to them when they were in fear and pain and the struggle of death. ${ }^{229}$

Although Gibbs was himself a Catholic, there seems little reason to doubt the veracity of his conclusions. Nevertheless, despite its overall accuracy, this picture still requires substantial qualification. Obviously, not all Catholic soldiers were living exemplars of Christian virtue. As a contemporary chaplin's anecdote ran, "When was your last confession?" "The last war, Father", 230 Significantly, while generally proud of the men to whom he ministered, William Doyle was by no means blind to their shortcomings. Even in the 16th Division, men continued to put buttons in the collection and to refer to confession as 'Scraping one's kettle'. ${ }^{231}$ After giving a general absolution on one occasion, Doyle recalled that one soldier shouted to him, "'Good-bye, Father, we are ready to meet the devil himself now"', which Doyle felt sure he subsequently did. $^{232}$ Assailed by moral temptation, Catholic soldiers frequently fell into sins of impurity, and at least one young Catholic soldier admitted falling into mortal sin by losing his virginity in a French brothel. ${ }^{233}$ These considerations no doubt help to explain the rather ambivalent tone of Charles Plater's Catholic Soldiers, a book which sought to answer the question of 'How has the religion of Catholic soldiers in the British Empire stood the test of war?' Now practically forgotten, Plater's work represented a unique survey of lay Catholic attitudes and practices and was intended to be the Catholic counterpart to the inter-denominational Army and Religion report, the project being inspired by Plater's established interest in the spiritual welfare of Catholic soldiers and by a meeting with the committee responsible for compiling its Protestant counterpart. Like The Army and Religion, Catholic Soldiers was published in 1919 and employed the same primary method of data collection, namely the circulation of a 
standard questionnaire to chaplains, officers and men. Plater's questionnaire posed ten questions, the answers it elicited being supplemented with material drawn from his correspondence programme. ${ }^{234}$ The questions asked how the war had affected the faith of the men and what it had revealed of their religious knowledge, their religious practice and their moral failings. They asked about the return of lapsed Catholics to the sacraments and also for examples of conspicuous piety. they also inquired about the behaviour of the wounded, the behaviour of the condemned, the conduct of officers, about relations between chaplains and their men and, finally, about the general effects of the war on the moral and religious character of Catholic soldiers. Plater's survey, which also embraced the Dominion and American armies, was the most thorough investigation into the faith and behaviour of Catholic soldiers produced by the war and its findings described a Catholic subculture within the British army whose characteristics were often at variance with those portrayed by the wartime Catholic press.

With respect to whether the war had unsettled the religious faith of 'any large proportion of Catholic men', the overwhelming verdict was that it had not, Plater even going so far as to claim that "not one clear case appears in all the reports and letters in which a Catholic soldier has been unsettled in his belief in God by the war. ${ }^{235}$ An English chaplain with extensive experience of the front line provided some explanation for this, 'Our men are not puzzled as non-Catholics are by God's allowing war', he wrote, 'they understand it is a consequence of sin-of free-will badly used.' ${ }^{236}$ Nevertheless, despite Plater's confidence, his informants did divulge some borderline cases. A chaplain with varied experience of the Western Front and of camps in England remembered:

At the present, out of three years' experience, I can only remember one instance of a Catholic soldier bringing forward the problem of evil difficulty. This was a wounded man in a Base Hospital. He did not wish to receive the Sacraments, and said, as one reason for his objection, that if the Catholic religion were true, God would protect Catholics in a special manner from wounds and death. He gave me the impression of a man who had led a loose life and neglected his religion for many years. Another man, an infantry man in the line, and an old soldier, refused on the ground that this killing business was murder, and it was impossible to be a real Catholic and Christian while a soldier on active service. This man was of the same type as the other, a tough sort of fellow, who, I should think, had not practised his religion for many years previous to the war. ${ }^{237}$

Significantly, the perplexity caused by the deaths of Catholics and the destruction of churches was not an isolated phenomenon, being mentioned by at least one other British chaplain. ${ }^{238}$ A Canadian informant also volunteered that the Pope's neutrality was a cause of widespread comment and recurrent complaint. ${ }^{239}$ Moreover, Catholic soldiers had not refrained from using terms such as 'fate' and 'luck', although Plater's respondents were generally agreed that in both cases soldiers 
used them casually as 'synonyms for God's will'. ${ }^{240}$ Similarly, most respondents were convinced that Catholic soldiers had used devotional aids not as charms but 'in a Catholic sense'. Nevertheless, one chaplain had indicated that even men who avoided the sacraments were glad to receive rosaries, and that in such cases he presumed that 'there must be a vague hope that the rosary will protect them from being hit' ${ }^{241}$ Whatever the light in which they were seen and used, one chaplain averred 'men, like boys, like anything they can get. You can't load them up with too many scapulars, crucifixes, medals, etc. ${ }^{, 242}$

As for the proportion of men who seemed 'fairly well instructed in their religion', ${ }^{243}$ Plater's informants demonstrated a broader range of opinion. According to a chaplain with more than three years of experience with front-line troops from Lancashire and Middlesex, about 80 per cent were 'fairly well instructed.' Nevertheless, he maintained, 'the number of Catholics who know nothing whatever of their religion, and have never been to the Sacraments, is very large'. The same chaplain also drew attention to the childish rather than childlike quality of the faith of many of the men:

The war has proved the enormous value of Catholic elementary schools, and has shown their chief weakness, religion not made spontaneous enough, too much a part of school discipline. In a religious sense, crowds of our men have never grown up at all,- their religious ideas, their prayers, and their ideas of sin remain just as they were at, say, thirteen years old. ${ }^{244}$

Among British chaplains, estimates as to the proportion of the ffairly well instructed' among their flocks ranged from ninety-nine per cent to one-third, ${ }^{245}$ estimates which reflected regional and national variations which were already apparent in late Victorian British Catholicism. ${ }^{246}$ Observers were unanimous that, among British soldiers during the First World War, those from the south of England were generally weakest in their religious knowledge whilst those from Ireland and Lancashire were generally much better informed. As a chaplain with four and a half years' experience put it:

99 out of 100 Irish would explain correctly Immaculate Conception, difference between Resurrection and Ascension, who was Pontius Pilate, how do you baptize, -in fact anything. The English often don't know these things, or say they don't, not being sure. I except Lancashire men, who equal Irish in all respects, and exceed them in Apostolic zeal. Lancs [men] are always bringing up lapsed Catholics or try to convert Protestants. ${ }^{247}$

In terms of religious practice, which Plater defined as daily personal prayer and 'coming occasionally to the Sacraments', there was unanimity that, at the very least, the majority of men fulfilled their Easter duties. ${ }^{248}$ Moreover, even many of those who avoided the Sacraments could be relied upon to come to Mass and say their prayers. ${ }^{249}$ Otherwise, levels of attendance at the sacraments varied according to the stage of the war, the religious composition of units and the proximity of physical danger. It is indicative of the response of Catholics to 
the call for volunteers during the first months of the war that Plater's informants identified not only a decline in the relative number of Catholics as the war progressed but also a perceptible decline in their religious fervour. According to one chaplain with four years' experience of hospital work in England:

I found a very great difference in the men in the first eighteen months of the war and after. In that first period Catholics were in the proportion of 1 to 4 and were all anxious to receive whatever benefits they could from the Church. In the latter part the men were mainly conscripts and many Catholics seemed to be indifferent, and the proportion of Catholics was 1 to 15 or $16 .^{250}$

Again, a chaplain with extensive service with Welsh troops in Egypt and Palestine, reported:

The number of Catholics seemed to dwindle during the latter part of the war-no doubt, I should say, because the stock was getting used up. It seems to prove that Catholics came forward readily in the early days. ${ }^{251}$

As Plater observed, these changes had considerable implications for those Catholics who remained in the army, not least because 'where Catholics are few and scattered they are apt to be less keen on the practice of their religion, partly, no doubt, because they cannot be looked after so well by the chaplain (if they have one) and partly because they lack the backing of public opinion. ${ }^{, 252}$ However, one factor which would stir the faith of even the most lukewarm Catholic was the immediate prospect of death or wounding. As one chaplain put it, 'speaking roughly, the fervour of the men's Catholicity was at any moment proportioned to the amount of danger that was to be faced. 253 Consequently, religion flourished 'more in the line than further back', Catholics being generally keen to receive the sacraments before going into the line or prior to an attack. ${ }^{254}$ However, this phenomenon was not confined to the infantry alone, one chaplain noting how the increasing effectiveness of German counter-battery fire rendered Catholic gunners on the Western Front 'very easy to induce to Confession and Communion' during the latter stages of the war. ${ }^{255}$ Significantly, as one chaplain recounted, the experience of its first battle worked wonders among the Catholics of one division. This chaplain recalled how a mission held in England prior to their departure for France brought only ten per cent of the division's Catholics to holy communion on its concluding Sunday. On arrival in France, this mood of apparent indifference continued to prevail among these untried soldiers. Then, in the autumn of 1915, came the battle of Loos. "At Loos we had a terrible gruelling, and lost half our effectives', the chaplain recalled, 'The effects on the spirituals of the survivors were marvellous. When we got back into billets, where we stayed refitting for about a fortnight, I was busy in the confessional of a village church every single night. ${ }^{, 256}$ Nor were Catholic chaplains disparaging about 
what could be described as 'funk religion' in other quarters. The same chaplain wrote:

To the objection that this was a religion of fear and superstition, my answer is that faith in the four last things had been dormant, and it had taken heavy artillery to wake it up. But the faith was there, and when it woke up, the men knew what they had to do, and realized its real importance. ${ }^{257}$

The answers to Plater's question as to the frequency, circumstances and effects of 'moral falls' would have made painful reading for many at home and would not have been palliated by the common assertion that the moral conduct of Catholics was generally better than that of the run of their comrades. A large number of chaplains admitted that moral falls were certainly frequent among their men, even if almost universally followed by 'sorrow, contrition, and a promise of amendment.' 258 Not only was drunkenness, petty theft and foul language endemic, but sexual sins were also relatively common. With regard to such cases, the chaplains cited by Plater demonstrated a Liguorist sympathy for the sinner if not for the sin, fully appreciating the bad example of others and also the terrible circumstances of the front-line soldier. One chaplain made a particularly vivid plea of extenuation:

A man was for weeks and sometimes several months at a time living in an area of desolation ... Then for one giddy, glittering day, he is given an outing in Amiens, or, in the latter days of the war, in Paris. He is given quite a lot of money. He goes in company with a crowd of the normal pagans, labelled C. of E., and the lot of them, who, for weeks and months have never seen a woman, let alone been for years separated from mothers, sisters [and] wives, are set upon by harpies. Surely big excuses can be made for the Catholic who, under abnormal conditions such as these, followed the crowd into one of the innumerable brothels. ${ }^{259}$

As Plater termed it, quite apart from the existence of a small but reliable cadre of exemplary Catholics, ${ }^{260}$ 'the most encouraging section' of his report concerned the return of 'negligent and slack Catholics' to the practice of their religion under the circumstances of the war. On the basis of the evidence to hand, Plater claimed that 'there can be no doubt that enormous numbers of Catholics have returned to the practice of religion during the war, after many years of absence: and that this has not been only or mainly due to fear. ${ }^{261}$ As his witnesses testified, those who refused the sacraments when 'comered' were few indeed. Moreover, changed personal circumstances, a new priest and the example of fellow Catholics could all serve to entice those who had fallen away in civilian life back to the sacraments. ${ }^{262}$ Among the wounded, the desire for the sacraments was particularly marked. One chaplain noted that the calm induced by his ministrations among the Catholics who passed through his field ambulance eventually persuaded the doctors to look on him 'as a help, especially for men who were shouting in pain and upsetting others. ${ }^{263}$ Another mentioned how all reticence disappeared in such circumstances; 'when wounded they want 
the Sacraments, and lose all shyness. One has to tell them at times that they must not confess now, owing to their weakness or the nearness of bystanders, or that they must lower their voices as others are lying near. ${ }^{264}$ Such devotion had a tendency to set the tone among the Catholic wounded, a third chaplain remarking how, in the whole of his experience, he had encountered only 'two or three men who refused the Sacraments when dying' after attending 'thousands of men in the battlefield and in hospitals. ${ }^{265}$ Another constituency among whom the ministrations of a priest appear to have been welcome was among the condemned. No chaplain found a prisoner under sentence of death unresponsive to the comforts of religion and one non-Catholic was even received into the Church on the eve of his execution. ${ }^{266}$ One of the most vivid stories recounted by Plater's informants concerned a twentyyear old lapsed Catholic from London who sent for a priest only when his death sentence was confirmed the day before he was to be shot. The chaplain concerned heard his confession, gave him Holy Communion, said the rosary and prayers for the dying with him 'and entreated him to offer his life for the cessation of the miseries of war'. Significantly, when led out the following morning, the man held his rosary beads 'in his manacled hands behind his back. ${ }^{267}$

The example and co-operation of Catholic officers was generally applauded by the chaplains involved in Plater's survey. The consensus was that such officers had played a key rôle in liaising between chaplains and Catholic soldiers and in setting a good religious example for the men. As one chaplain put it, 'officers led their men in religious practices as they did when they went 'over the top.' I had only a few Catholic officers in the division I worked with, but they never failed me. ${ }^{268}$ One chaplain even testified that a Catholic colonel of the Grenadier Guards had ensured that all the Catholics in his battalion had performed their Easter duties before going back into the line in 1915. ${ }^{269}$ In terms of the war making men 'more accessible to the priest', ${ }^{270}$ the war had had the double effect of enabling priests to reach men whom they would have scarcely had access to in civilian life while also diminishing their level of contact with the more devout. ${ }^{271}$ What was also detected was an identifiable lack of spontaneity in asking for the sacraments or in searching out the times and places of Masses when out of the line. One chaplain even spoke of 'the impressive bovinity of the faithful' in this regard. ${ }^{272}$ Although chaplains expressed some exasperation at this lack of initiative and at generally having to root Catholics out, at least one thought that this was more a function of army psychology than an indication of religious indifference:

lack of 'spontaneity,' so often commented on, in asking for the Sacraments, must be viewed within a general soldier-psychology. Where no order is given, there is little action. A certain vagueness, indecision, lack of initiative is visible throughout most soldiers' private lives. ${ }^{273}$ 
Significantly, what Plater described as 'the official rank and ambiguous uniform of the chaplain ${ }^{, 274}$ had not served to create a gulf between chaplains and their men. A shared faith uncomplicated by party differences seemed to ensure what was described as an 'immediate rapport' between Catholic soldiers and their chaplains. ${ }^{275}$ Moreover, this was assisted by the jealousy with which Catholic chaplains appear to have guarded their sacerdotal rôle, one which was not obscured by rank or by secondary preoccupations. As one chaplain wrote of the men:

They do not expect the priest to be a society entertainer or a vendor of buns or cigarettes. The fact of a priest being an officer in no way puts a barrier between him and the Catholic men. To them he is not Captain A. or Major B., but just 'the priest.' They never address the priest as 'Padre,' but by the English title, 'Father.'276

In its overall assessment of effect of the war on 'the moral and religious character of men', Catholic Soldiers presented a view which was broadly consistent with the picture presented by Gibbs. In the short term at least, Catholic soldiers had not felt compelled to grapple with disturbing questions of theodicy, they had been responsive to their priests and to the sacraments and the war had helped to make good Catholics better and to reclaim, at least temporarily, a good many of those who had leaked away in civilian life. However, despite these positive results, there were less encouraging aspects of the report. One of its consistent features had been to underline considerable regional variations in the religious education and religious practice of British Catholics. Moreover, the circumstances of service life had evidently exposed Catholics to a number of dangerous influences. Not only was this fact already manifest in a high incidence of moral failure but at least one chaplain looked with trepidation towards the possible longterm effects of other harmful circumstances:

They have been in countries where people were Catholics in name only. They have been so circumstanced for so long that they have not been able to practise their religious duties regularly, and have in consequence come to regard the obligation as less binding: and there is a great danger that they will retain the same tendency at home. ${ }^{277}$

Upon publication, Catholic Soldiers was instantly seized upon by the Catholic press as a means of belabouring the Protestant churches. With reference to the two complementary reports on religion in the army, a reviewer for The Tablet wrote, 'it is for the reader to draw conclusions as to which organised body has stood the test of war, and the task will not impose too great a strain upon any unprejudiced mind ... The Catholic Church has made good during the war and let us not allow our countrymen to forget it. ${ }^{278}$ However, as David Cairns, the principal author of The Army and Religion, subsequently pointed out, his report had dealt not with the active members of a single denomination but with ninety-five per cent of the British army. Moreover, as Cairns declared, careful consideration of Plater's conclusions did not warrant 
such an euphoric tone. No doubt because of its mixed findings, Catholic Soldiers soon began to be viewed more circumspectly by Catholic commentators. Writing only three years after its publication, Plater's biographer, Fr. Cyril Martindale S.J., announced his deep misgivings as to the whole project, 'I cannot pretend I ever thought this a wise plan,' he wrote, 'nor do I think it was successfully carried out. ${ }^{, 279}$ In Martindale's opinion, the book was lacking in hard statistical data, was poorly circulated and consequently failed to inspire much debate. On the whole, he maintained, the whole business amounted to 'much labour nearly wasted'. ${ }^{280}$ Notwithstanding Martindale's dismissive views, the issues raised in Catholic Soldiers help to betray the true intent behind much of the feverish activity which occurred on the home front in connection with the spiritual needs of Catholic soldiers, particularly during the latter years of the war. Clearly, the unspoken fears behind much of this activity were those of vice and leakage. With Catholic soldiers often thinly scattered throughout the army, having little contact with their chaplains and mixing with men of all types and shades of opinion, the experience of army life threatened to negate the earlier, positive influences of Catholic schools, Catholic clubs and Catholic institutions. Although the Catholic Soldiers' Association existed for the purpose of assisting 'Catholic soldiers in the practice of their religion', by 1915 this organisation was experiencing considerable difficulty in meeting the demands of the time and its subsequent efforts were clearly not sufficient to allay the fears of some. ${ }^{281}$ In 1917 , Bishop Casartelli embarked upon a course of encouraging the young men of Salford Diocese to volunteer for Irish regiments rather than to await the call-up and be thrust thereafter into less congenial environments. ${ }^{282}$ Moreover, given Catholic fears of souperism and sheepstealing and suspicions which had concerned the proselytising intent of Protestant soldiers' homes and institutes in pre-war years, ${ }^{283}$ the proliferation of wartime soldiers' huts run by non-Catholic groups and denominations served to put Catholics on their guard. As Casartelli declared in 1917, Catholic huts were not only useful but absolutely necessary, notwithstanding the good faith recently shown by some agencies, and most notably the Y.M.C.A., in providing recreational facilities for Catholic soldiers and makeshift accommodation for Catholic worship. $^{284}$

This article has sought to shed some initial light on the British Catholic experience of the First World War. Coming after a period of growing integration into British public life, the war offered a golden opportunity for the consolidation and even advancement of this process. Catholic enthusiasm for the war in mainland Britain stemmed from a number of factors, many of which were shared by the nation at large, but conspicuous among them was the desire of the Catholic press and hierarchy to promote Catholic interests by ensuring a ready response to the war effort by the Catholic laity in general and by its men of military 
age in particular. However, the politics of Catholic Ireland and the position maintained by Pope Benedict XV came close to subverting the impressive efforts made by British Catholics in support of the war. In view of this, and as the war lengthened, the example of the Catholic soldier became ever more important in countering a growing tide of public resentment towards Catholic Ireland and Pope Benedict XV, resentment which, given Britain's long history of anti-Catholicism, could conceivably have assumed far more dangerous proportions in the bitter and heated atmosphere of wartime Britain. However, Catholic soldiers not only provided the best demonstration of Catholic loyalty for the public at large in these difficult times but were also portrayed as exemplars of their faith, thus helping to make the war more palatable to Catholics at home and lending credibility to Catholic assumptions of superiority over rival denominations. However, although heavily romanticised by the Catholic press and benefiting from some unjust criticisms of the Church of England, army Catholicism does appear to have been both robust and expansive during the war years, part of its success no doubt stemming from its existing strengths in civilian life. Moreover, at a time when most Protestant observers deplored the religious ignorance of the average British Tommy and concurred that less than twenty per cent of Britain's citizen soldiers were meaningfully linked to any church, ${ }^{285}$ the contrasting degree of religious knowledge and level of religious commitment demonstrated by their Catholic peers served as a considerable source of Catholic satisfaction. However, as Charles Plater's Catholic Soldiers demonstrated, this picture of Catholic confidence and vitality was somewhat deceptive, an impression which is strengthened given the anxiety betrayed by many forms of Catholic activity during the war years. Nevertheless, when Plater's rather unpalatable volume was published in 1919 it was already a book that few wanted to read or digest. The more controversial aspects of Catholic wartime activity, most notably the tally of British Catholic war dead and the bishops' lack of meaningful support for Benedict XV's position in favour of their own pursuit of narrower national interests, were apparently forgotten in the aftermath of the war. Not that the difficult times which followed the signing of the Armistice were conducive to reflection of this kind. In the immediate aftermath of the war, the Catholic hierarchies of England and Scotland were faced with a raft of urgent problems which ranged from the implementation of the Church's new code of canon law to dealing with influenza and social unrest at home and with Republican insurgency across the Irish Sea. In succeeding years, as levels of immigration from an embittered and antiBritish Irish Free State grew in the 1930s to continue for years thereafter, the importance of the war years diminished in the collective consciousness of a changing Catholic community, declining to the point where it now stands, that is to a point where the popular Catholic 


\section{experience of these momentous years is routinely omitted from the pages of British Catholic history.}

\section{NOTES}

The author would like to acknowledge the invaluable assistance of Rev. David Lannon, Rev. Dr. John Sharp, Gerard Tracey, Dr. John Bourne and Andrew Snape in the preparation of this article. This article is dedicated to the memory of his grandfather, Francis Snape, and to his brothers who fought in the First World War.]

1 See, for example, A. J. Hoover, God, Germany, and Britain in the Great War: a Study in Clerical Nationalism (New York, 1989); A. Marrin, The Last Crusade: the Church of England in the First World War (Durham N.C., 1974); A. Wilkinson, The Church of England and the First World War (London, 1978) and Dissent or Conform? War, Peace and the English Churches 1900-1945 (London, 1986); S. J. Brown, "'A Solemn Purification by Fire": Responses to the Great War in the Scottish Presbyterian Churches', Journal of Ecclesiastical History, 45, 1994, pp. 82-104; D. Thompson, 'War, the Nation and the Kingdom of God: the Origins of the National Mission of Repentance and Hope, 1915-16' in W. J. Sheils (ed.), 'The Church and War', Studies in Church History, 20, 1983, pp. 337350; A. Becker, War and Faith: the Religious Imagination in France, 1914-1930 (Oxford, 1998).

2 S. Mews, 'Religious Life between the Wars, 1920-1940' in S. Gilley and W. J. Sheils (eds.), A History of Religion in Britain (Oxford, 1994), p. 452.

${ }^{3}$ E. Norman, Roman Catholicism in England (Oxford, 1985), p. 108. See also G. A. Beck (ed.), The English Catholics 1850-1950 (London, 1950); V. A. McClelland and M. Hodgetts (eds.), From Without the Flaminian Gate: 150 Years of Roman Catholicism in England and Wales (London, 1999); E. E. Reynolds, The Roman Catholic Church in England and Wales (Wheathampstead, 1973); D. Mathew, Catholicism in England (London, 1948).

${ }_{4}^{4}$ M. Dungan, They Shall Grow Not Old: Irish Soldiers and the Great War (Dublin, 1997), pp. 61-73; J. Hagerty, 'Benedictine Military Chaplains During the First World War', English Benedictine Congregation History Symposium, 1998, pp. 134-151; T. Johnstone and J. Hagerty, The Cross on the Sword: Catholic Chaplains in the Forces (London, 1996), pp. 71-189; J. Leonard, Catholic Chaplaincy (Dublin, 1986); M. Moynihan (ed.), God on Our Side (London, 1983), pp. 174-210; T. Denman, Ireland's Unknown Soldiers: the I6th (Irish) Division in the Great War (Blackrock, 1992) and 'The Catholic Irish soldier in the First World War: the "racial environment", Irish Historical Studies, 27, 1990-91, pp. 352-365; T. P. Dooley, Irishmen or English Soldiers? (Liverpool, 1995).

5 T. Bartiett, "A Weapon of War Yet Untried": Irish Catholics and the Armed Forces of the Crown, 1760-1830' in T. G. Fraser and K. Jeffery (eds.), Men, Women and War (Dublin, 1993), p. 77.

6 W. Gordon Gorman (ed.), Converts to Rome: a Biographical List of the More Notable Converts to the Catholic Church in the United Kingdom during the last sixty years (London, 1910), names 116 army officers as converts up to the date of publication.

7 The Times, 4 May 1893, p. 5.

8 F. C. Burnand (ed.) The Catholic Who's Who (London, 1909), pp. 65-66; 266-67.

${ }^{9}$ I am grateful to Dr. J. M. Bourne for this information.

${ }^{10}$ E. M. Spiers, 'Army Organisation and Society in the Nineteenth Century' in T. Barlett and K. Jeffery (eds.), A Military History of Ireland (Cambridge, 1996), p. 337. The General Annual Report of the British Army for the year ending 30 September 1913 (London, 1914) gives figures of 33,662 Roman Catholics and 20,780 Irish-born soldiers of all denominations.

11 The General Annual Report of the British Army, 1913.

12 The Tablet, 7 August, 1915, p. 184; Anon., The Catholic Prayer Book Compiled Chiefly for the Use of Soldiers (London, 1891), pp. 259-260.

${ }_{13}$ F. Forde, 'Liverpool Irish Volunteers', Irish Sword, 10, 1971-72, pp. 106-23.

${ }_{14}$ F. Segesser, The Catholic Boys' Brigade (London, 1903), p. 6.

15 Salford Diocesan Archives [hereafter SDA], Catholic Boys' Brigade and Cadets, Box 186/25.

16 The Oratory School Magazine, 57, March 1916, p. 12.

17 Ibidem, 54, July 1914, pp. 18-20.

18 T. E. Muir, Stonyhurst College 1593-1993 (London, 1992), pp. 106, 127.

19 E. Oldmeadow, Francis Cardinal Bourne (London, 1944), vol. II, pp. 106-7.

${ }^{20}$ Gordon Gorman, op. cit., p. 44.

21 T. Denman, "Ethnic Soldiers Pure and Simple"? The Irish in the Late Victorian British Army', War in History, 3, 1996, pp. 264-266.

22 Johnstone and Hagerty, pp. 38-39.

23 The Harvest, August 1916, pp. 143-45.

24 D. M. MacRaild, Irish Migrants in Modern Britain, 1750-1922 (Basingstoke, 1999), p. 152.

25 D. W. Miller, Church, State and Nation in Ireland 1898-1921 (London, 1973), pp. 304-7.

26 P. Callan, 'Recruiting for the British Army in Ireland during the First World War', Irish Sword, 17, 1987-90, p. 52.

27 L. Colley, Britons: Forging the Nation 1707-1837 (London, 1992), p. 327 
28 B. Griffin, 'Irish Identity and the Crimean War' in B. Taithe and T. Thornton (eds.), Themes in History: War (Stroud, 1998), p. 118.

29 T. Denman, 'Irish Politics and the British Army List: the Formation of the Irish Guards in 1900', Irish Sword, 19, 1995, pp. 172-185 and "The red livery of shame": the campaign against army recruiting in Ireland, 1899-1914', Irish Historical Studies, 29, 1994-95, pp. 208-233.

30 S. Fielding, Class and Ethnicity: Irish Catholics in England, 1880-1939 (Buckingham, 1993), p. 43.

${ }^{31}$ S. Gilley, 'The Years of Equipoise, 1892-1932' in McClelland and Hodgetts (eds.), p. 34; G. Elliot Anstruther, A Hundred Years of Catholic Progress (London, 1929), pp. 116-17.

32 Anon., Catholics of the British Empire and the War (London, 1916), p. 4.

33 Gilley, 'The Years of Equipoise' in McClelland and Hodgetts op. cit., p. 35; Brown, 'Solemn Purification by Fire', p. 101; J. Wolffe, 'Change and Continuity in British Anti-Catholicism' in F. Tallett and N. Atkin (eds.), Catholicism in Britain and France Since 1789 (London, 1996), pp. 75-77.

${ }^{34}$ Tablet, 8 August 1914 , p. 200.

${ }^{35}$ The Catholic Federationist, September 1914, p. 2.

36 Oldmeadow, Francis Cardinal Bourne, vol. II, p. 107

37 Tablet, 8 August 1914, p. 205; L. Casartelli, The Terrible Year: an Advent Pastoral Letter (Salford, 1914), p. 25.

38 Tablet, 8 August 1914, p. 204.

39 Catholic Federationist, September 1914, p. 2.

40 Ibidem.

41 W. Barry, The Knights of the Red Cross. A Sermon Preached at the Requiem for Fallen Catholic Soldiers \& Sailors Belonging to the Catholic Missions of Birmingham, in St. Chad's Cathedral, before the Archbishop and Clergy, on June I, 1915 (London, 1915), pp. 9-10.

42 Casartelli, Terrible Year, p. 23.

${ }^{43}$ Tablet, 29 August 1914, p. 312

44 Oldmeadow, Francis Cardinal Bourne, vol. II, pp. 109-110; W. Ward, 'German Catholics and the War'. The Dublin Review, 158, 1916, p. 13; C. Lattey, The Church in Germany at the Present Day (London, 1913).

${ }^{45}$ Harvest, October 1914, p. 245.

46 Tablet, 9 January 1915, p. 82.

47 W. Barry, Memories and Opinions (London, 1926), p. 271.

${ }^{48}$ L. Casartelli, Auxilium Christianorum: a Lenten Pastoral Letter (Salford, 1916), pp. 87-88; W. Barry, 'Is Turkey Doomed?', Dublin Review, 159, 1916, p. 179; The Month, 127, 1916, p. 382. For a study of Barry's influential views on the war see S. Gilley, 'Father William Barry: Priest and Novelist', Recusant History, 24, 1999, pp. 545-549.

${ }^{49}$ Month, 127, 1916, p. 382.

50 lbidem, December 1916 , vol. 128 , p. 556.

51 Denman, Ireland's Unknown Soldiers, pp. 19-37.

52 M. Middlebrook, Your Country Needs You (Barnsley, 2000), p. 147

${ }^{53}$ Callan, 'Recruiting for the British Army in Ireland;, p. 54.

${ }^{54} \mathrm{H}$. Hanna, The Pals at Suvla Bay being the record of ' $D$ ' Company of the 7th Royal Dublin Fusiliers (Dublin, 1917), pp. 136, 138

${ }_{55}$ Over a period of nine months in 1915 , well before the impact of the Easter Rising was felt on Nationalist politics, 45 per cent of recruits for the Connaught Rangers and 31 per cent of recruits for the Royal Dublin Fusiliers enlisted in mainland Britain (see Callan, 'Recruiting for the British Army in Ireland', p. 46). Such a situation was facilitated by the fact that the army did not concern itself with issues relating to the ethnic purity of its regiments. In fact, as the commandant of the Irish Guards confessed in 1917, the army did not have an official view as to what an Irishman was, 'anyone professing to be of Irish nationality' being eligible to join an Irish regiment. SDA Box 162, Bishop Casartelli's Copy Letters, Box 162, undated July 1917.

56 While being formed in 1915, three battalions of the 16th (Irish) Division were fleshed out with volunteers from the Channel Islands Militias (Middlebrook, Your Country Needs You, pp. 52-53). In terms of replacements, after suffering heavy losses around Ypres in August 1917 the 7th Leinster Regiment received over 100 replacements from the King's Shropshire Light Infantry, the progressive dilution of the battalion's Irish character being reflected in the fact that only 57 per cent of its fatal casualties for 1917 were Irish-born (T. Denman, 'An Irish battalion at war: from the letters of Captain J. H. M. Staniforth', Irish Sword, 17, 1987-1990, p. 172). The use of English conscripts as replacements for Irish regiments was controversial given Ireland's successful opposition to conscription and the practice was protested with some success by English M.P.s in the House of Commons (Middlebrook, Your Country Needs You, p. 146).

57 Middlebrook, Your Country Needs You, pp. 50, 52-53, 146.

58 D. Fitzpatrick, 'Militarism in Ireland, 1900-1922' in Barlett and Jeffery (eds.), A Military History of Ireland, pp. 387-388.

${ }_{59}$ M. J. Walsh, 'Catholics, Society and Popular Culture' in McClelland and Hodgetts op. cit., p. 347.

60 Tablet, 17 July 1915 , p. 84.

61 Forde, 'Liverpool Irish Volunteers', p. 111.

62 For a contemporary account of the raising of the Tyneside Irish Brigade see J. Keating 'The Tyneside Irish Brigade' in F. Lavery (ed.), Irish Heroes in the War (London, 1917), pp. 37-131. 
${ }^{63}$ M. J. Hickman, Religion, Class and Identity: the State, the Catholic Church and the Education of the Irish in Britain (Aldershot, 1995), pp. 111-120, 173-181.

${ }^{64}$ Fielding, Class and Ethnicity, pp. 40-43.

65 Gilley, 'Years of Equipoise' in McClelland and Hodgetts (eds.), p. 28.

66 J. Fox, Forgotten Divisions (Wilmslow, 1994), p. 18.

${ }^{67}$ Fielding, Class and Ethnicity, p. 76.

68 Hickman, Religion, Class and Identity, pp. 180-181.

69 Federationist, October 1914, p. 5.

70 Tablet, 17 July 1915 , p. 84.

71 Ibidem, 24 October 1914, p. 583.

72 In November 1914 Bishop J. S. Vaughan wrote to the Manchester Guardian that 'a small man ... presents a smaller target to the enemy's guns . . . and is as a rule more combative and mettlesome than his weightier brethren . . . From Caesar to Napoleon and from Napoleon to our "Bobs", some of the greatest soldiers have been some of the smallest men,' Tablet, 5 December 1914, p. 765.

73 Catholic Federationist, January 1915, p. 1.

74 lbidem.

75 Catholics of the British Empire, p. 8.

76 Tablet, 12 September 1914, p. 377.

77 D. S. Cairns (ed.), The Army and Religion an Enquiry and its Bearing on the Religious Life of the Nation (London, 1919), p. 189.

78 Catholics of the British Empire, p. 7.

79 A. Hastings, A History of English Christianity (London, 1991), p. 135.

80 Lavery (ed.), Irish Heroes in the War, pp. 108, 111.

81 The Catholic Directory, Ecclesiastical Register and Almanac (London, 1914), p. 623.

82 Tablet, 21 August 1915, p. 242.

83 Diocese of Salford, Ad Ven Clerum, 14 January 1915, p. 90; Catholic Federationist, February 1915, p. 1 .

84 Almanac of the Diocese of Salford, 1916, (Salford, 1916), pp. 78-80.

85 Catholics of the British Empire, p. 70.

${ }^{86}$ Diocese of Salford, Catholic Protection and Rescue Society Annual Report, 1915, p. 3.

87 Tablet, 12 September 1914 , p. 379

88 Ibidem, 5 September 1914, p. 356.

89 Ibidem, 3 October 1914, p. 475.

90 Catholics of the British Empire, pp. 7-8.

91 The Catholic Directory (1914), p. 625.

92 1. Beckett, 'The Nation in Arms, 1914-18' in I. F. W. Beckett and K. Simpson (eds.), A Nation in Arms (Manchester, 1985), Table 1.3, p. 11.

93 This estimate seeks to take into account the Catholic presence in reserved occupations such as shipbuilding, mining and munitions.

${ }_{94}$ Callan, 'Recruiting for the British Army in Ireland', p. 53; General Annual Report of the British Army, 1913.

95 Catholic Federationist, February 1915, p. 1

96 Tablet, 28 November 1914, p. 728.

9741 men out of 252 have been identified as Roman Catholics. See W. Tumer, Accrington Pals (London, 1992), pp. 204-209. According to Catholic sources, the Catholic population of Lancashire was 666,767 out of a total population of 4,820,508. See The Catholic Directory (1914), p. 623 .

98 C. Plater, 'A Letter to a Catholic Soldier', Catholic Social Guild Leaflets, 6 (Fifth Impression), 1916 , p. 1.

99 S. Fowler, W. Spencer and S. Tamblin, Army Service Records of the First World War (Public Record Office Publications, 1997), p. 1.

100) Anon. For the Front: Prayers and Considerations for Catholic Soldiers (Market Weighton, 1918), p. 42 .

${ }_{101}$ D. Devas, From Cloister to Camp (London, 1919), pp. 92-93.

102 Birmingham Archdiocesan Archives, FHD/A5 Francis H. Drinkwater, War Diaries 1915-18 (bound typescript), 8 January and 17 February 1916.

${ }_{103}$ A. Bellenger, 'Cardinal Gasquet (1946-1929): An English Roman', Recusant History, 24, 1999, pp. 556-57.

${ }_{104}$ F. Bourne, 'Union Sacrée': Great Britain in War Time (London, 1917), p. 2.

105 Oldmeadow, Francis Cardinal Bourne, vol. II, p. 109; Becker, War and Faith, pp. 85-86.

106 Becker, War and Faith, pp. 95-96; Diocese of Salford, Ad Ven Clerum, 23 May 1917, pp. 109-110.

107 Month, 132, September 1918, pp. 221-22. Foch, in turn, was not unappreciative of their efforts, describing their gift of 30,000 communions as 'a great act of faith'. See Tablet, 15 March 1919, p. 305. 108 Catholics of the British Empire, p. 8.

109 Ibidem, pp. 70-72.

${ }_{110}$ Ibidem, pp. 32-8.

111 Tablet, 3 July 1915, p. 17. See also accounts of Sergeant Michael O'Leary's reception at Dublin (Tablet, 10 July 1915, p. 49) and at Archbishop's House, Westminster (Tablet, 24 July 1915, p. 129).

112 Ibidem, 24 July 1915, p. 129.

113 Tablet, 3 July 1915, p. 17. 
114 Month, 127, January 1916, p. 181.

1 is Catholics of the British Empire, p. 6.

116 Month, 129, January 1917, pp. 70-72.

117 Ibidem, 129, January 1917, p. 79.

118 Catholics and the British Empire, p. 68.

119 D. W. Miller, Church, State and Nation in Ireland 1898-1921 (Dublin, 1973), pp. 312-13.

120 Ibidem, p. 312; Johnstone and Hagerty, Cross on the Sword, pp. 185-86. Oldmeadow asserts that, by Easter 1915. Westminster had released more secular priests to the army than had all of the Irish dioceses put together. Oldmeadow, Francis Cardinal Bourne, vol. II, p. 119.

121 Miller, Church, State and Nation, pp. 406-6.

122 P. Coffey, 'The Conscription Menace in Ireland and some Issues raised by it', Irish Ecclesiastical Record, Fifth Series, 11, June 1918, pp. 484-98, 486-87.

123 C. Plater (ed.), A Primer of Peace and War: the Principles of International Morality (London, 1915), pp. 262-3.

124 E. I. Watkin, Roman Catholicism in England from the Reformation to 1950 (London, 1958), p. 221.

125 J. F. Pollard, The Unknown Pope: Benedict XV (1914-1922) and the Pursuit of Peace (London, 1999), p. 123.

126 Oldmeadow, Francis Cardinal Boume, vol. II, pp. 110-11.

127 Brown, “"A Solemn Purification by Fire"”, p. 101.

${ }^{128}$ N. Cave, 'Haig and Religion' in B. Bond and N. Cave (eds.), Haig: A Reappraisal Seventy Years On (Barnsley, 1999), p. 245.

129 'The Haig Papers from the National Library of Scotland. Part 1: Haig's Autograph Great War Diary' (Harvester Microform, Brighton, 1987), Reel 5, 15 October 1917.

${ }^{130}$ T. Denman, 'The '6th (Irish) Division on 21 March 1918: Fight or Flight?', Irish Sword, 17, 198790 , p. 285.

131 Plater (ed.), A Primer of Peace and War, pp. 249-265; 'S.F.S.', 'The Popes as Peacemakers', Month, 130, July 1917, pp. 3-14; A. Brennan, Pope Benedict XV and the War (London, 1917).

132 'John Bull' and the Pope: Some Plain Words on a Plain Issue (London, 1918), pp. 3-13.

133 Month, 131, March 1918, pp. 281-2.

134 Ibidem, 132, August 1918, pp. 153-4.

135 Tablet, 25 September 1915, p. 444.

136 Month, 131, March 1918, pp. 281-2.

137 Plater, 'Letter to a Catholic Soldier', p. 2.

${ }^{138}$ H. C. Day, A Cavalry Chaplain (London, 1922), p. 18.

139 Drinkwater, War Diaries, 11 August 1915.

140 The Oratory, 126, July 1918, p. 2.

141 Imperial War Museum, Department of Documents, A. Essington-Nelson 86/48/1, scrapbook 14 April 1916.

${ }_{142}$ M. ÓhUanacháin, "A Few Notes on German Treatment": The diary of Sergeant Charles Mills, Royal Munster Fusiliers, 1918', Irish Sword, 15, 1982-3, p. 167.

143 J. Bickersteth (ed.), The Bickersteth Diaries (London, 1996), p. 72.

144 I.W.M., Department of Documents, J. G. Bennett 97/33/1.

145 Johnstone and Hagerty, Cross on the Sword, p. 102.

146 P. Macgill, The Great Push (Dingle, 1984), pp. 183-85 (first pub. 1916); for accounts of Macgill's life and views see also B. Aspinwall, 'Patrick Macgill, 1890-1963: an alternative vision' in D. Wood (ed.), 'The Church and the Arts', Studies in Church History, 28, 1992, pp. 499-513 and D. Taylor, "A Little Man in a Great War": Patrick Macgill and the London Irish Rifles' in Taithe and Thornton (eds.), Themes in History: War, pp. 235-249.

147 R. Graves, Good-Bye To All That (London, 1929), p. 276.

148 H. C. Foster, At Antwerp and the Dardanelles (London, 1918), p. 84.

149 A. O'Rahilly, Father William Doyle, S.J. (London, 1932), pp. 432, 460, 474, 505.

150 M. Heimann, Catholic Devotion in Victorian England (Oxford, 1995), pp. 156-61; Cairns (ed.), The Army and Religion, passim.

151 Day, A Cavalry Chaplain, p. 129.

152 R. Kipling, The Irish Guards in the Great War (London, 1923) 2 vols, passim: Denman, 'The Catholic Irish Soldier in the First World War', pp. 361-63; Dooley, Irishmen or English Soldiers?, pp. 185-190.

${ }_{153}$ Tablet, 12 December 1914, p. 796.

154 W. Barry, The Knights of the Red Cross. A Sermon Preached at the Requiem for Fallen Catholic Soldiers and Sailors Belonging to the Catholic Missions of Birmingham, in St. Chad's Cathedral, before the Archbishop and Clergy, on June 1,1915 (London, 1915), pp. 12; 14.

155 A British Cardinal's Visit to the Western Front (London, 1918), p. 15.

156 T. Denman, A Lonely Grave: The Life and Death of William Redmond (Blackrock, 1995), p. 15.

157 Catholic Federationist, July 1917, p. 7; SDA Casartelli correspondence, Box 162, 4304, 11 June 1917.

${ }^{158}$ B. Williamson, 'Happy Days' in France and Flanders (London, 1921), p. 64

159 Tablet, 3 October 1914, p. 481.

160 Ibidem, 10 October 1914, p. 513; 17 October 1914, p. 547

161 Heimann, Catholic Devotion, p. 156; For the Front, p. 32. 
162 C. C. Martindale, Charles Dominic Plater S.J. (London, 1922), pp. 215-37.

163 Harvest, April 1917, p. 69.

164 Tablet, 8 May 1915, p. 599; 22 May 1915, p. 671.

165 Ibidem, 29 May 1915, p. 705.

166 Catholic Federationist, May 1917, p. 1.

167 Anon., C.W.L. Soldiers' Recreation Huts, undated, n.p.

168 Plater, 'Letter to a Catholic Soldier', p. 2.

169 For the Front, p. 42.

170 Tablet, 20 February 1915, p. 233.

171 lbidem, 20 February 1915, pp. 233-234.

172 Martindale, Charles Dominic Plater S.J., p. 221.

173 Tablet, 27 February 1915, p. 274.

174 O'Rahilly, Father William Doyle, p. 405.

175 Becker, War and Faith, pp. 47-59. Becker's work, however, is hampered by the fact that she considers it 'impossible to undertake a statistical study' of these men.

176 The Catholic Directory (1914), p. 623; Norman, Roman Catholicism in England, p. 109.

177 O'Rahilly, Father William Doyle, p. 528.

178 G. Stebbing, The Position and Prospects of the Catholic Church in English-Speaking Lands (Edinburgh, 1930), pp. 249-50.

179 Hagerty, 'Benedictine Military Chaplains', p. 138.

180 See Drinkwater, War Diaries and Williamson, Happy Days', passim.

181 See, for example, Tablet, 6 January 1917, p. 15.

182 M. Ward, Resurrection Versus Insurrection (London, 1937), p. 470

${ }_{183}$ Miller, Church, State and Nation, p. 312.

184 J. H. Thompson, 'The Free Church Army Chaplain' (Sheffield Ph.D., 1990) p. 346.

185 Bickersteth (ed.), Bickersteth Diaries, p. 181.

186 Thompson, 'Free Church Army Chaplain', pp. 308-9; Johnstone and Hagerty, Cross on the Sword, p. 174.

${ }_{187}$ G. Parsons, 'Victorian Roman Catholicism: Emancipation, Expansion and Achievement' in G. Parsons (ed.), Religion in Victorian Britain, volume I: Traditions (Manchester, 1988), pp. 171-72; Heimann, Catholic Devotion, pp. 158-59; H. McLeod, Religion and Society in England, 1850-1914 (Basingstoke, 1996), pp. 85-86.

188 G. Gordon, 'The Chaplain's Dilemma' in T. W. Pym and G. Gordon, Papers from Picardy (London, 1917), pp. 108-9.

${ }^{189}$ Bickersteth (ed.), Bickersteth Diaries, p. 197; J. Britten, 'Anglicanism at the Front', Month, 126, October 1915, p. 384.

${ }_{190}$ L. Creighton (ed.) Letters of Oswin Creighton, C.F. 1883-1918 (London, 1920), p. 199.

191 Graves, Good-Bye To All That, p. 243.

192 A. Wheatley (ed.), Father Dolly The Guardsman Monk: the Memoirs of Captain the Right Reverend Dom Rudesind Brookes OBE MC TD OSB (London, 1983), p. 29.

${ }^{193}$ Wilkinson, Church of England and the First World War, pp. 129-31. After the war, this view achieved additional permanence through the memoirs of Robert Graves. See Good-Bye to All That, p. 242.

194 Johnstone and Hagerty, Cross on the Sword, p. 88; O'Rahilly, Father William Doyle, pp. 433-34.

195 Drinkwater, War Diaries, 16 March 1918.

196 Tablet, 14 November 1914, p. 659.

197 Norman McLean and J. R. P. Sclater, God and the Soldier (London, 1917), pp. 210-19.

198 P. Fussell, The Great War and Modern Memory (Oxford, 1977), pp. 131-35.

199 Month, 'War Shrines', 129, January 1917, pp. 67-70; C. Moriarty, 'Christian Iconography and First World War Memorials', Imperial War Museum Review, 6, pp. 69-70.

200 S. Williams, Religious Belief and Popular Culture in Southwark (Oxford, 1999), pp. 61-75.

201 Tablet, 20 February 1915, p. 234.

202 O'Rahilly, Father William Doyle, p. 497.

203 Month, 126, July 1915, pp. 74-77.

204 Tablet, 2 June 1917, p. 695.

205 E. C. Vaughan, Some Desperate Glory (London, 1982), p. 193.

206 Heimann, Catholic Devotion, p. 67.

207 Tablet, 10 February 1917, p. 173.

208 Heimann, Catholic Devotion, pp. 66-67; The Oratory, 120, January 1918, pp. 2-3; Irish Ecclesiastical Record, Fifth Series, 12, November 1918, pp. 421-22.

209 P. C. T. Crick, 'The Soldier's Religion' in F. B. MacNutt (ed.), The Church in the Furnace: Essays by Seventeen Temporary Chaplains on Active Service in France and Flanders (London 1917), pp. 352 55; Cairns (ed.), The Army and Religion, pp. 100-121.

${ }_{210}$ Tablet, 13 March 1915 , p. 332

21 Britten, 'Anglicanism at the Front', p. 381.

212 M. Whitehead, 'A View From the Bridge: the Catholic School' in McClelland and Hodgetts op. cit., p. 231.

213 G. Parsons, 'Victorian Roman Catholicism', p. 179.

214 Ward, Insurrection Versus Resurrection, p. 469. 
215 Drinkwater, War Diaries, 15 August 1918.

216 McLeod, Religion and Society, pp. 40-41.

217 Hastings, History of English Christianity, p. 135; C. Noel, 'Organized Labour: the Working Classes' in W. K. Lowther Clarke (ed.), Facing the Facts (London, 1911), pp. 105-6; C. G. Brown, Religion and Society in Scotland since 1707 (Edinburgh, 1997), p. 118.

218 J. Bourne, 'The British Working Man in Arms' in H. Cecil and P. Liddle (eds.), Facing Armageddon: the First World War Experienced (London, 1996), pp. 336-352.

${ }^{219}$ L. I. Guiney, 'An Oxford Private: Arthur Brandreth, M.A.', Month, 129, February 1917, pp. 12932.

220 J. Winter, 'Army and Society' in Beckett and Simpson (eds.), p. 196.

$221 \mathrm{~J}$. Bourne, 'The British Working Man in Arms', p. 345

222 Hastings, History of English Christianity, p. 137; D. Hempton, 'Religious Life in Undustrial Britain, 1830-1914' in S. Gilley and W. J. Sheils (eds.), A History of Religion in Britain (Oxford, 1994), p. 313.

${ }^{223}$ Williamson, 'Happy Days' in France and Flanders, pp. 18-20.

224 Devas, From Cloister to Camp, p. 24.

225 Drinkwater, War Diaries, 2 September 1917.

226 First Army Pilgrimage to Lourdes (London, 1918); Catholic Federationist, July 1918, p. 1.

227 Hagerty and Johnstone, Cross on the Sword, pp. 151-154.

228 Harvest, 31, December 1918, pp. 196-7.

${ }^{229}$ P. Gibbs, Realities of War (London, 1920), p. 440.

${ }^{230}$ Drinkwater, War Diaries, 10 September 1915

${ }^{231}$ O'Rahilly, Father William Doyle, pp. 463; 502

232 Ibidem, p. 404

${ }^{233}$ J. Bourke, Dismembering the Male: Men's Bodies, Britain and the Great War (London, 1996), pp. $159-60$

${ }_{234}$ Martindale, Charles Dominic Plater, pp. 345-46

235 C. Plater (ed.), Catholic Soldiers by Sixty Chaplains and Many Others (London, 1919), p. 9.

236 Ibidem, p. 11.

237 lbidem, pp. 13-14.

238 Ibidem, p. 10.

239 Ibidem, p. 13.

240 Ibidem, p. 18.

241 Ibidem, p. 29.

242 Ibidem, p. 26.

243 Ibidem, p. 33.

244 Ibidem, p. 34.

${ }^{245}$ Ibidem, p. 38.

246 Parsons, 'Victorian Roman Catholicism', pp. 166-67.

247 Ibidem, pp. 36; 149.

248 Ibidem, p. 41.

249 Ibidem, p. 53.

250 lbidem, p. 42.

251 lbidem.

252 lbidem.

253 lbidem, p. 50

254 Ibidem, p. 48

255 Ibidem.

256 Ibidem, p. 55.

257 Ibidem.

258 Ibidem, p. 88.

259 Ibidem, p. 78.

260 Ibidem, pp. 96-106

261 Ibidem, p. 89.

262 Ibidem, pp. 90; 93.

263 Ibidem, p. 107.

264 Ibidem.

$265 \mathrm{Ibidem}$, p. 113.

266 Ibidem, p. 126.

${ }^{267}$ Ibidem, p. 128.

268 Ibidem, p. 131.

269 Ibidem, p. 130.

270 Ibidem, p. 135.

271 Ibidem.

272 Ibidem, p. 136.

273 lbidem, p. 120.

274 Ibidem, p. 135.

275 Ibidem, p. 139.

276 Ibidem, p. 140. 
277 Ibidem, p. 149.

278 Tablet, 14 February 1920, p. 210.

279 Martindale, Charles Dominic Plater, p. 238.

280 lbidem, p. 239.

281 Tablet, 7 August, 1915, p. 184.

282 Catholic Federationist, August 1917, p. 1.

283 F. Maurice and G. Arthur, The Life of Lord Wolseley (London, 1924), p. 266.

${ }^{284}$ Catholic Federationist, May 1917, p. 1.

${ }^{285}$ Cairns (ed.), The Army and Religion, p. 189. 